\title{
A new species of Cricosaurus (Thalattosuchia, Metriorhynchidae) based upon a remarkably well-preserved skeleton from the Upper Jurassic of Germany
}

\author{
Sven Sachs, Mark T. Young, Pascal Abel, and Heinrich Mallison
}

\begin{abstract}
Herein we describe a new and exceptionally well-preserved skeleton of the metriorhynchid thalattosuchian Cricosaurus from the upper Kimmeridgian Torleite Formation of Painten in Bavaria (Southern Germany). The specimen is articulated, shows soft-tissue preservation, and represents one of the most complete metriorhynchid skeletons known. The exceptional preservation allows us to explore the morphological variation of the tail region in the Metriorhynchidae, a part of the skeleton that has long been neglected. Based on our description and phylogenetic analyses, we name this specimen Cricosaurus albersdoerferi sp. nov. Our phylogenetic analyses recover a Cricosaurus subclade composed of four species from Southern Germany and one from Argentina. We provide revised diagnoses for the Southern German members of this subclade, revealing the presence of at least four closely-related Cricosaurus species in the upper Kimmeridgian-early Tithonian of Southern Germany. Interestingly, within this subclade there is evidence of rapid change in tail construction and feeding ecology. However, there is no evidence of sympatry between these taxa, and the two species known from the same ammonite subzone are exclusively found in different northernTethys lagoons. Most interesting, however, is the variation in the skulls, dorsal neural spines, the tail displacement units, and flukes between these different species. This previously unexplored variation within Metriorhynchidae hints to differences in locomotory abilities between different species.
\end{abstract}

Sven Sachs. Naturkunde-Museum Bielefeld, Abteilung Geowissenschaften, Adenauerplatz 2, 33602 Bielefeld, Germany, and Im Hof 9, 51766 Engelskirchen, Germany. Sachs.Pal@gmail.com Mark T. Young. School of GeoSciences, Grant Institute, University of Edinburgh, James Hutton Road, Edinburgh, EH9 3FE, UK. Mark.Young@ed.ac.uk Pascal Abel. Senckenberg Centre for Human Evolution and Palaeoenvironment, Eberhard-KarlsUniversität Tübingen, Sigwartstraße 10, 72076 Tübingen, Germany pascal.abel@ifg.uni-tuebingen.de], Heinrich Mallison. Palaeo3D, Dorfstr. 11, 86641 Rain am Lech, Germany and CeNak, Universität

http://zoobank.org/2667E3D2-BC97-48C5-89B6-C5AD87C10D82

Sachs, Sven, Young, Mark T., Abel, Pascal, and Mallison, Heinrich. 2021. A new species of Cricosaurus (Thalattosuchia, Metriorhynchidae) based upon a remarkably well-preserved skeleton from the Upper Jurassic of Germany. Palaeontologia Electronica, 24(2):a24. https://doi.org/10.26879/928

palaeo-electronica.org/content/2021/3371-a-new-cricosaurus-species

Copyright: June 2021 Paleontological Society.

This is an open access article distributed under the terms of Attribution-NonCommercial-ShareAlike 4.0 International (CC BY-NC-SA 4.0 ), which permits users to copy and redistribute the material in any medium or format, provided it is not used for commercial purposes and the original author and source are credited, with indications if any changes are made. creativecommons.org/licenses/by-nc-sa/4.0/ 
Hamburg, Martin-Luther-King-Platz 3, 20146 Hamburg, Germany. mallison@palaeo3d.com

Keywords: Metriorhynchidae; Cricosaurus; Upper Jurassic; Torleite Formation; Germany; new species

Submission: 28 September 2018. Acceptance: 18 May 2021.

\section{INTRODUCTION}

The Upper Jurassic limestones of the Altmühl valley in Bavaria (Southern Germany) are well known for their exclusively well-preserved vertebrate fossils (e.g., Arratia et al., 2015). They have yielded iconic specimens, such as the dinosaurs Archaeopteryx and Compsognathus; numerous pterosaurs, but also aquatic tetrapods including turtles, pleurosaurs, ichthyosaurs, and thalattosuchian crocodylomorphs (see Arratia et al., 2015 and references therein). The first thalattosuchian remains described from these units were named Crocodilus priscus (now Aeolodon priscus, a teleosauroid) and Lacerta gigantea (now Geosaurus giganteus, a metriorhynchid) by von Sömmerring $(1814,1816)$. They were also the first thalattosuchian taxa to be formally named in scientific publications (Young et al., 2018).

Subsequently, a number of thalattosuchian specimens have been reported from localities in the Altmühl valley, the majority of which are metriorhynchids (Frey and Tischlinger, 2015). Metriorhynchidae is a clade of pelagic crocodylomorphs that were geographically widespread in the Late Jurassic (e.g., Frey et al., 2002; Buchy et al., 2006; Gasparini et al., 2006; Young et al., 2010; Herrera et al., 2013a, 2015). The metriorhynchids of Southern Germany are of special importance because of their unique preservation in terms of articulation and completeness. In contrast to this the clay pits of Peterborough UK yielded hundreds of metriorhynchid fossils that are found disarticulated, often incomplete, and taphonomically deformed (e.g., Andrews, 1913; Foffa and Young, 2014; Foffa et al., 2018; MTY pers. obs.). Thus, elucidating the postcranial morphology of Metriorhynchidae, determining how variable it is, and investigating macroevolutionary trends are frustratingly difficult.

The genus Cricosaurus was established by Wagner (1858) for material discovered in the Altmühl valley. The type species, Cricosaurus elegans (Wagner, 1852), is based on a complete but dorsoventrally crushed skull. When Wagner (1858) established the genus Cricosaurus, he also erected two additional species, $C$. grandis and $C$. medius. Today, C. grandis is considered to be a species of Geosaurus (Young and Andrade, 2009), while the holotype of $C$. medius was thought to be lost until recently (see Sachs et al., 2019; Herrera et al., 2021a). For over 100 years Cricosaurus was considered to be a subjective junior synonym of Geosaurus (first proposed by Fraas, 1902), until Young and Andrade (2009) split the two genera. Cricosaurus is now known as a geographically widespread taxon, with fossils discovered in Upper Jurassic strata of Europe, South America, and North America, as well as Lower Cretaceous strata of western Europe (e.g., Frey et al., 2002; Young and Andrade, 2009; Herrera et al., 2013a, 2021a, 2021b; Sachs et al. 2020).

Complete skeletons of Cricosaurus, however, are rare. The postcranial anatomy is so far only known for Cricosaurus suevicus Fraas, 1901 (initially described as Geosaurus suevicus by Fraas, 1901) from the upper Kimmeridgian strata of Nusplingen (Baden-Württemberg, SW Germany) and $C$. bambergensis Sachs, Young, Abel, and Maillison, 2019 from the upper Kimmeridgian strata of Wattendorf (Bavaria, Southern Germany). The postcranial skeleton of $C$. araucanensis (Gasparini and Dellapé, 1976), from the early late Tithonian of Argentina, is known from incomplete and partially articulated skeletons (Herrera et al., 2009, 2013b, 2017). Accordingly, the morphological variation of the postcranial skeleton is largely unknown.

This research describes and names a new articulated skeleton (BMMS-BK 1-2, Figure 1) that is one of the most complete and best-preserved Cricosaurus fossils on record. The specimen is on display at the Bürgermeister-Müller-Museum in Solnhofen (Germany) and derives from the Upper Jurassic Torleite Formation. It was found in 2002 by Raimund Albersdörfer in the Rygol quarry in Painten, Bavaria (Southern Germany). BMMS-BK 1-2 has not been described before and yields new information on the cranial and postcranial anatomy of the genus Cricosaurus, revealing a previously underappreciated diversity in tail morphology within Metriorhynchidae. Furthermore, with the data gleaned from the specimen we revise the diagnoses for most of the Cricosaurus species of the late Kimmeridgian-to-early Tithonian of Southern Germany. 


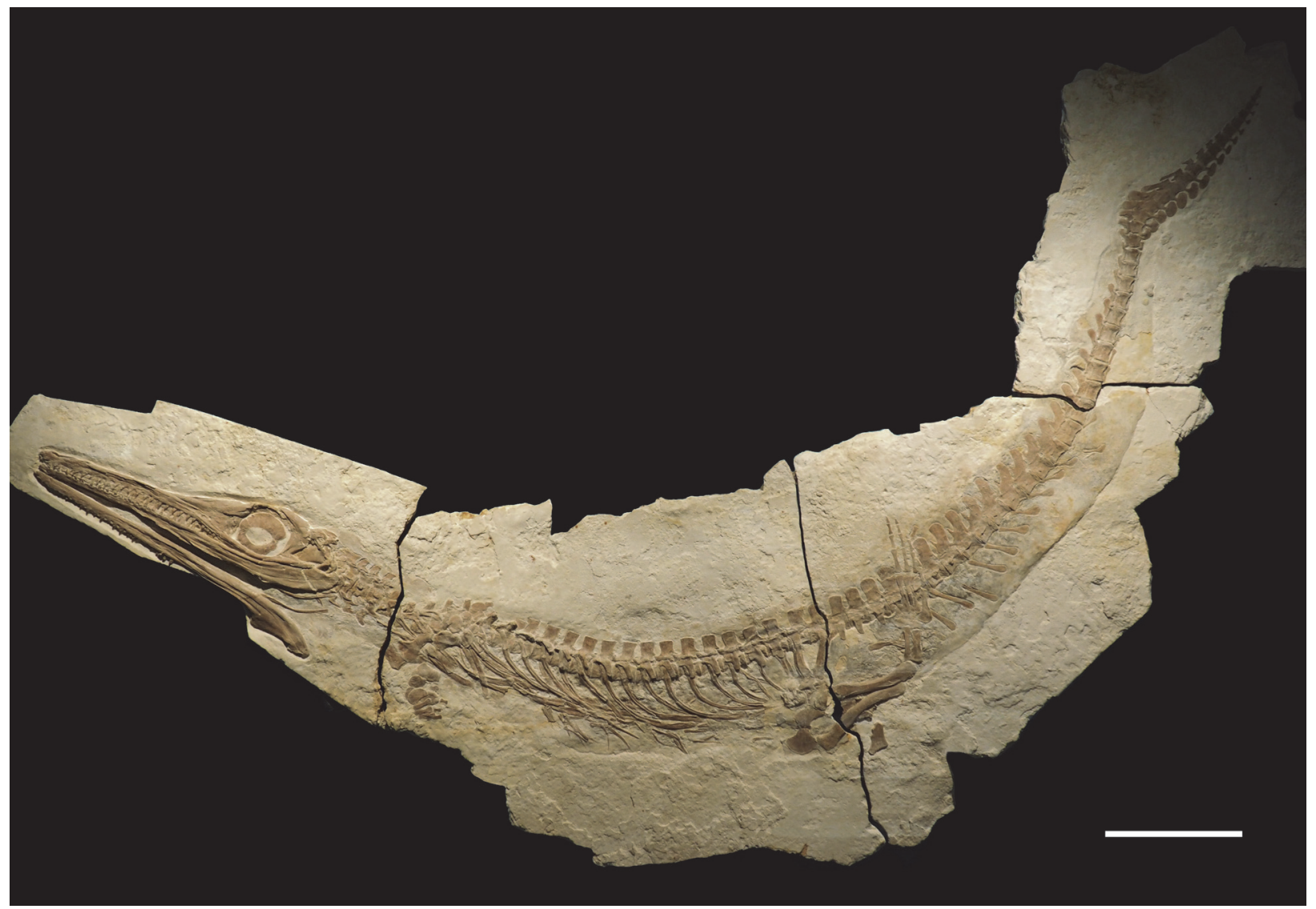

FIGURE 1. Cricosaurus albersdoerferi sp. nov. (BMMS-BK 1-2) holotype, late Kimmeridgian of Painten (Southern Germany). Skeleton in lateral view. Scale bar equals $200 \mathrm{~mm}$.

Institutional abbreviations. BMMS, Bürgermeister-Müller-Museum Solnhofen, Germany; GPIT, Palaeontological collections Tübingen, Senckenberg Centre for Human Evolution and Palaeoenvironment, Eberhard-Karls-Universität Tübingen, Tübingen, Germany; NAMU, Naturkunde-Museum Bielefeld, Bielefeld, Germany; NKMB, NaturkundeMuseum Bamberg, Bamberg, Germany; NHMUK, Natural History Museum, London, UK; SMNS, Staatliches Museum für Naturkunde Stuttgart, Germany; SNSB-BSPG, Staatliche Naturwissenschaftliche Sammlungen Bayerns-Bayerische Staatssammlung für Paläontologie und Geologie, Munich, Germany.

\section{GEOLOGY AND STRATIGRAPHY}

BMMS-BK 1-2 was found in the upper Kimmeridgian Torleite Formation (Figure 2), which forms the most basal formation of the Upper Weißjura Group in Bavaria and can be divided into geographically differing members. Its lithology represents a carbonate rock succession, dominated by lithographic as well as thin siliceous limestones
('Plattensilex'). The formation ranges from the upper Aulacostephanus pseudomutabilis to the upper Hybonoticeras beckeri Tethyan ammonite Zones (Niebuhr and Pürner, 2014).

The specimen dates to the Hybnoticeras beckeri Tethyan ammonite Zone and Lithacoceras ulmense Subzone of the Arnstorf Member in the eastern Franconian Jura. The Arnstorf Member is characterized by the dominating siliceous limestones ('Plattensilex'). Lithographic limestones are less abundant (Schweigert, 2007; Niebuhr and Pürner, 2014). The matrix BMMS-BK 1-2 is embedded in is a white-coloured thin and fine-laminated siliceous limestone.

\section{PALAEOENVIRONMENT}

The rocks of the Arnstorf Member were deposited in the 'Painten lagoon' of the Solnhofen archipelago, and the high abundance of land plants suggests it was a near-shore environment. Aside from marine reptiles like thalattosuchians and turtles (Spindler and Albersdörfer, 2019), the lagoon was most notably inhabited by a vast diversity of 


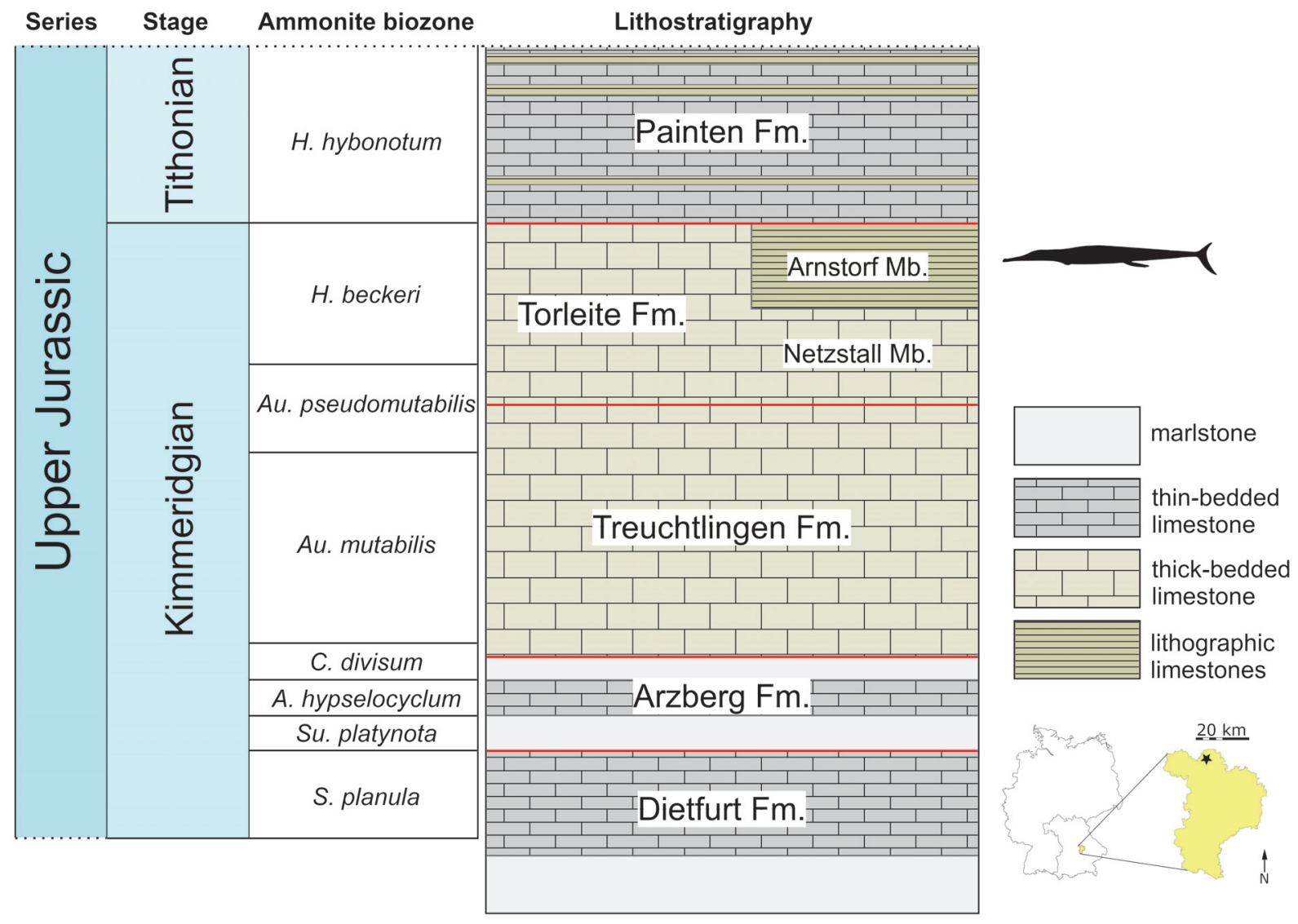

FIGURE 2. Simplified stratigraphy of the Upper Jurassic in the eastern Franconian Jura, highlighting the fossil-bearing horizon (silhouette). The type locality within the Kelheim district is indicated by a black star.

non-tetrapod Osteichthyes as well as a high abundance of 'teuthid' cephalopods. The presence of the latter indicates that the lagoon was mostly open to the marine realm (Röper, 2005). In addition to Cricosaurus, other articulated metriorhynchid fossils have been discovered from the Painten lagoon (including so far unpublished specimens, such as two large geosaurines and a juvenile metriorhynchid) (Spindler and Albersdörfer, 2019).

\section{LEGAL STATEMENT AND DATA PERMANENCE}

BMMS-BK 1-2 was given as a permanent loan to the Bürgermeister-Müller-Museum (BMMS) in Solnhofen by palaeontologist Raimund Albersdörfer. Mr. Albersdörfer is well known for providing valuable specimens to science, including, among others, the unique skeletons of the theropod dinosaurs Sciurumimus albersdoerferi and Archaeopteryx albersdoerferi. BMMS-BK 1-2 is on display at the Bürgermeister-Müller-Museum since 2008 and has been figured in textbooks with the Bürgermeis-
ter-Müller-Museum as its permanent depository (Frey and Tischlinger, 2015).

It is guaranteed by contract (deposited at the BMMS) that BMMS-BK 1-2 will always be available in the public domain. This contract stipulates that the specimen is officially curated by the Bürgermeister-Müller-Museum, and that it will not be sold to a non-public entity. BMMS-BK 1-2 thus has the same legal status as Sciurumimus albersdoerferi (BMMS-BK 11, permanent loan by Mr. Albersdörfer to the Bürgermeister-Müller-Museum), Archaeopteryx albersdoerferi (SNSB-BSPG VN-2010/1, permanent loan by Mr. Albersdörfer to the Bayerische Staatssammlung für Paläontologie und Geologie) and other recently described specimens from the Altmühl valley (e.g., Foth et al., 2014; Rauhut et al., 2012,2018 ) or the limestones of Wattendorf (Joyce and Mäuser, 2020) (but see also discussion in Haug et al., 2020).

In addition we created a high-resolution 3D digital photogrammetric model of BMMS-BK 1-2 
(Appendix 1-3), based on methods detailed in Mallison and Wings (2014) (details on its creation in Appendix 3; reduced polygon count version available as Appendix 1). This model is deposited in the collection of the Naturkunde-Museum Bielefeld (NAMU) under the specimen number BMMS-BK 12 (contact at curator.naturkundemuseum@bielefeld.de). The data inferred from BMMS-BK 1-2 are thus permanently available in a second public repository. This scan can be studied by researchers on request and provides detailed information about all morphological aspects, the size and the colour of the specimen. All observations and conclusions reached in our manuscript can be confirmed through this $3 \mathrm{D}$ file and the high resolution 2D orthophoto made from it (Appendix 2; details on its creation in Appendix 3 ).

The 3D file also allows high-resolution 3D printing of a full-scale copy, which for most research purposes can also stand instead of the original fossil.

\section{SYSTEMATIC PALAEONTOLOGY}

\section{Superorder CROCODYLOMORPHA Hay, 1930} (sensu Nesbitt, 2011)

Suborder THALATTOSUCHIA Fraas, 1901 (sensu Young and Andrade, 2009)

Family METRIORHYNCHIDAE Fitzinger, 1843

(sensu Young and Andrade, 2009)

Genus CRICOSAURUS Wagner, 1858

Type species. Stenosaurus elegans Wagner, 1852 (sic) [following recommendation 67B of the International Commission on Zoological Nomenclature (ICZN) Code]. Now referred to as Cricosaurus elegans (Wagner, 1852) Wagner, 1858.

Etymology. 'Ring lizard'. крі́коऽ (kríkos) is Ancient Greek for ring, referring to the large scleral rings preserved in the orbits of the holotype.

Emended diagnosis. Metriorhynchid crocodylomorph with the following unique combination of characters: external surface of the dermatocranium is largely smooth, usually lacking conspicuous ornamentation; external nares separated by a bony premaxillary internarial bar, with the nares terminating posterior to the second maxillary alveoli; acute angle formed by the posterolateral and posteromedial processes of the frontal; dorsal margin of the supratemporal bar is lower than the posteromedial process of the frontal; orbits as large as the supratemporal fenestrae (at least in morphologically mature individuals); lateral margins of the prefrontals rounded in dorsal view; surangular and angular well-developed, anterolaterally exceeding beyond the anterior margin of the orbits; symphyseal part of the mandible low; dentition has variable labiolingual compression, with some species having teeth with a sub-circular cross-section and others with a sub-rectangular one; dentition is bicarinate, but the carinae are faint (i.e., a low carinal keel); calcaneum tuber absent or vestigial; proximal end of metatarsal I greatly enlarged (modified from Young and Andrade, 2009; Sachs et al., 2019; Herrera et al., 2021a, 2021b).

Cricosaurus albersdoerferi sp. nov. Figures 1, 3-7

zoobank.org/53679A64-7EC2-49D2-A222-D3103FDDDD84

Holotype. BMMS-BK 1-2, almost complete articulated skeleton (Figure 1).

Type locality. Rygol quarry, Painten, Bavaria, Germany.

Type formation. Arnstorf Member, Torleite Formation.

Type horizon. Lithacoceras ulmense Subzone, Hybonoticeras beckeri Tethyian ammonite Zone, upper Kimmeridgian, Upper Jurassic.

Geological provenance. Upper Jurassic. Lithacoceras ulmense Subzone, Hybonoticeras beckeri Tethyian ammonite Zone, upper Kimmeridgian.

Etymology. The species epithet albersdoerferi honours palaeontologist Raimund Albersdörfer for making the specimen available to science.

Diagnosis. A member of Cricosaurus with the following unique combination of characters (proposed autapomorphic characters are indicated by an asterisk *): bicarinate dentition, lacking conspicuous enamel ornamentation; tooth crowns in premaxilla, maxilla and dentary distinctly labiolingually compressed (shared with C. bambergensis, C. elegans, and C. suevicus); presence of pronounced reception pits for dentary tooth crowns on the lateral margins of the anterior and mid-maxilla (shared with C. bambergensis); presence of pronounced reception pits on the lateral margins of the middle dentary*; morphology of the tail displacement unit: the distal-most six preflexural vertebrae are very strongly posteriorly inclined and lie on top of the prezygapophyses of the adjacent vertebra with their posterior margins; the distal-most preflexural vertebra lacks the rod-like neural spine present in C. suevicus (SMNS 9808).

Cricosaurus albersdoerferi and C. suevicus share the following synapomorphies: (1) dorsal vertebrae neural spines are rectangular in lateral view; (2) almost all dorsal neural spines have flat dorsal margins; (3) the distal-most preflexural vertebra has a dorsoventrally deep hemapophysis, with a midline flange (i.e., unlike the rod-shaped 


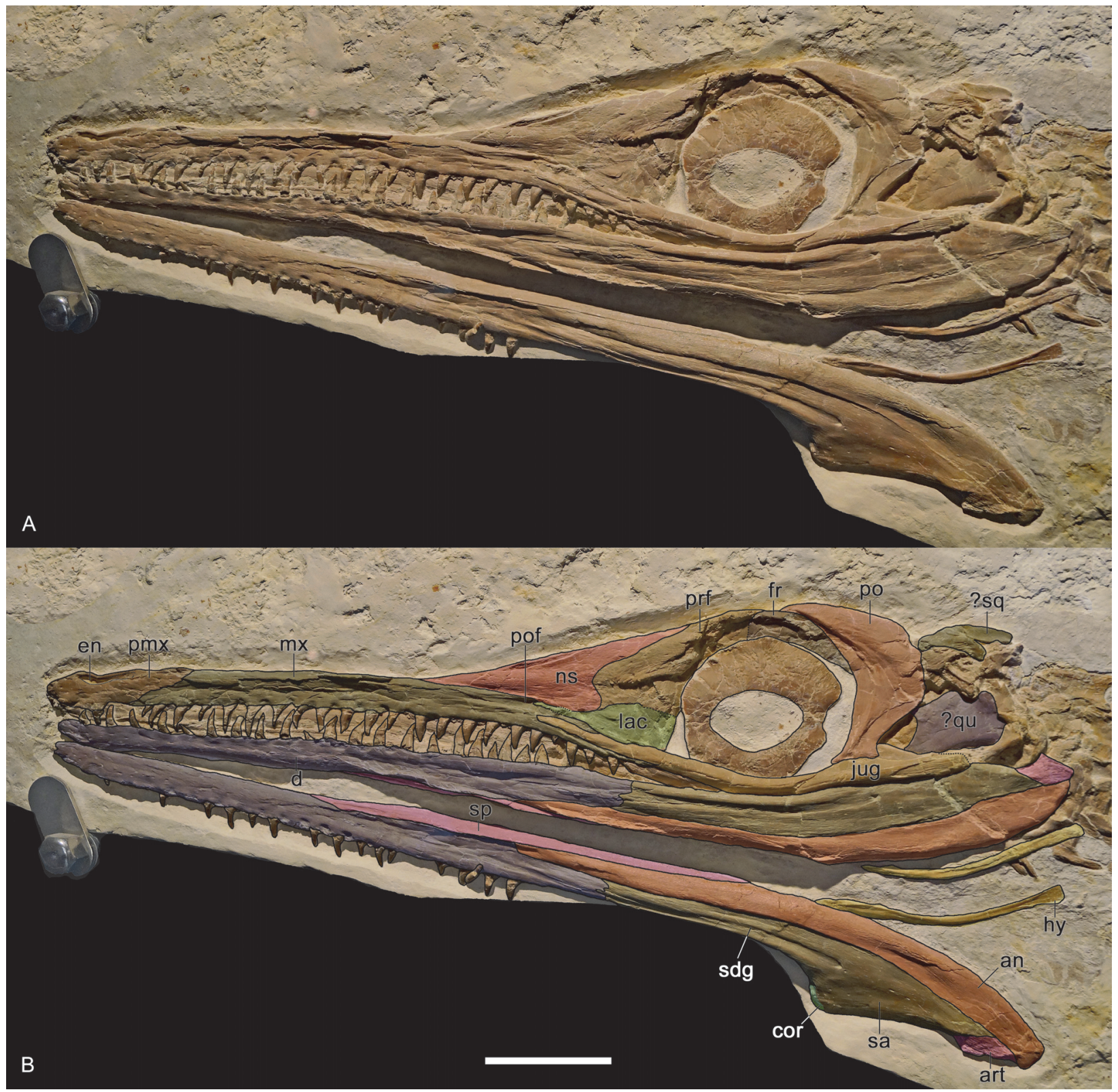

FIGURE 3. Cricosaurus albersdoerferi sp. nov. (BMMS-BK 1-2) holotype, late Kimmeridgian of Painten (Southern Germany). Skull in lateral view with illustration of the preserved elements. Abbreviations: an, angular; art, articular; cor, coronoid; d, dentary; en, external naris; fr, frontal; hy, hyoid; jug, jugal; lac, lacrimal; mx, maxilla; ns, nasal; pmx, premaxilla; po, postorbital; pof, preorbital fenestra; prf, prefrontal; ?qu, possible quadrate; sa, surangular; sdg, surangulodentary groove; sp, splenial; ?sq, squamosal or squamosal-postorbital fragment. Scale bar equals $50 \mathrm{~mm}$.

hemapophysis as in $C$. bambergensis NKMB-PWatt14/274 and Rhacheosaurus gracilis NHMUK PV R 3948 - see Sachs et al., 2019); (4) the fivesix proximal-most flexural caudal vertebrae have strongly anteriorly oriented neural spines (more prominently than in $C$. bambergensis NKMB-PWatt14/274, R. gracilis NHMUK PV R 3948 and
Thalattosuchus superciliosus GPIT-PV-31379); and (5) the flexural hemapophyses contact one another along their posteroventral-anterodorsal margins (not along their posterior-anterior margins as in C. bambergensis NKMB-P-Watt14/274, $R$. gracilis NHMUK PV R 3948 and T. superciliosus GPIT-PV-31379). 


\section{GENERAL REMARKS}

The skull of BMMS-BK 1-2 is largely complete and preserved in left lateral view with the left mandibular ramus still attached (Figure 3 ). The opposite right mandibular ramus is disarticulated and flipped to the side, likewise displaying the lateral aspect. The palatal and dorsal sides of the skull and the medial portions of the mandible are obscured by matrix. The occipital part is covered by bone fragments. Part of the dorsally placed external nares is likewise obscured by matrix. The circular orbit is placed in the posterior third of the skull and bears a prominent scleral ring. The posterior portion of the skull, formed by the quadrate, quadratojugal, and squamosal, is damaged and partly missing, as is the supratemporal fenestra and the posterior part of the infratemporal fenestra. The anterior frame of the latter is present as a semi-oval excavation that is demarcated by the jugal ventrally and by the postorbital anterodorsally. Several cranial sutures are difficult to trace as the skull was severely damaged and bears numerous cracks.

Some parts of the postcranial skeleton (several neural spines, phalanges, hemapophyses, and the distalmost caudal vertebrae) are covered by plaster or have been reconstructed to give the fossil a nicer and more complete appearance. These parts are not considered in the description of the specimen and are indicated in Appendix 4.

Premaxilla. The premaxillae are poorly preserved (Figure 3 ) and only the lateral aspect of the left premaxilla and part of its dorsal side are visible. The premaxillae frame the external nares, which have an anteroposteriorly elongate and transversely narrow appearance. A bony bridge placed dorsal to the external nares seems to have formed a septum separating them in the undistorted skull (see discussion in Young et al., 2020a). The external surface of the left premaxilla is irregular and bears some slit-shaped foramina. The premaxillary-maxillary suture is barely preserved and extends posteromedially. The exact number of premaxillary teeth cannot be provided as the alveolar part of the premaxilla is damaged, and only one posterior tooth is largely complete.

Maxilla. The left maxilla is exposed in lateral view (Figure 3). It is an anteroposteriorly elongate and dorsoventrally narrow element. While well preserved, the midsection of the maxilla is collapsed. The anterior premaxillary contact is indicated by a barely visible suture. Dorsally a long, straight, and posteriorly downcurved nasal contact is visible, and the preorbital fossa is evident posterodorsally, adjacent to the maxilla-nasal suture. Posteriorly the maxilla contacts the lacrimal via a long but barely visible suture. The maxillary midsection is mostly covered by the strip-shaped jugal. In lateral view, the maxilla appears to terminate approximately at level with the anterior edge of the orbit. Laterally a number of elongate slit-shaped foramina extend parallel to the tooth row. Twenty-three teeth can be counted, which vary in size. Reception pits are present between the second and $13^{\text {th }}$ maxillary tooth, whereas the alveolar margin is straight in the posterior maxilla.

Nasal. The nasals are prominent subtriangular elements that make up almost half of the preorbital portion of the skull roof (Figure 3). Ventrally a long, slightly curved maxillary suture is visible. Posteroventrally a short lacrimal contact is established. Here a reduced preorbital fenestra is placed that is, however, badly damaged by distortion. It seems that most of the frame of the preorbital fenestra is formed by the nasal and lacrimal with a minor contribution from the maxilla. On the posterior side the nasal contacts the prefrontal via a long and posterodorsally curved suture.

Lacrimal. The exposed left lacrimal is a subtriangular element (Figure 3). It has a curved posterior edge that forms the anteroventral demarcation of the orbit. Posterodorsally an irregular prefrontal contact is visible, and anterodorsally there is an about equally long lacrimal-nasal contact. The maxilla meets the lacrimal anteroventrally, and it is demarcated ventrally by the jugal. Anteriorly the lacrimal forms part of the preorbital fenestra.

Prefrontal. The left prefrontal is well preserved. It is a large, subtriangular element that forms the anterodorsal frame of the orbit (Figure 3). Ventrally, the prefrontal contacts the lacrimal and anteriorly a long, recurved prefrontal-nasal suture is visible. The dorsal part of the prefrontal overhangs the orbit with its rounded but damaged lateral side. The posterodorsal contact to the frontal cannot be determined due to the poor preservation of this part of the skull. The dorsal surface of the exposed left prefrontal is ornamented with a low number of pits and extensive number of grooves.

Frontal. The frontal is only partly exposed (Figure 3 ). It has a slightly convex dorsal surface and forms the dorsal frame of the orbit with its lateral portion. The anterior frontal-prefrontal and the posterior frontal-postorbital sutures cannot be traced.

Postorbital. The left postorbital is well preserved. It is a large bone that forms the entire posterior demarcation of the orbit with its concave anterior edge (Figure 3 ). The likewise concave posteroven- 
tral side of the postorbital forms the anterodorsal frame of the oval infratemporal fenestra. The midsection of the postorbital, forming the postorbital bar, is posteriorly expanded and wider than the dorsal and ventral portions of the element. The anterodorsal frontal contact cannot be determined due to numerous cracks. Ventrally a straight jugal suture is present.

Quadrate. A massive square-shaped but displaced bone is present in the infratemporal fenestra. It probably represents the quadrate displaying its posterior aspect (Figure 3 ).

Jugal. The left jugal is a strap-shaped, anteroposteriorly elongated, and dorsoventrally low element that forms the posteroventral demarcation of the skull (Figure 3). It extends far anteriorly to the level of the preorbital fenestra. Anteriorly the jugal overlies the posteriormost part of the maxilla and contacts the lacrimal anterodorsally. The slightly downcurved midsection of the jugal forms the ventral frame of the orbit. Posterior to the orbit the short jugal-postorbital contact is well defined. The posterior-most part of the jugal is broken off, but the preserved portion forms the ventral frame of the infratemporal fenestra.

Additional skull elements. Some fragments adjacent to the postorbital cannot be identified with certainty (Figure 3). Two elongate, slightly curved fragments placed adjacent to the postorbital appear be remnants of the squamosals or the conjoint squamosal-postorbital. A small, pointed fragment placed adjacent to the left postorbital appears to be part of the opposite postorbital element.

Dentary. The dentaries are well preserved and exposed in lateral view (Figure 3 ). The right ramus bears 22 teeth in situ, which vary in size. Sixteen teeth are preserved in the left ramus. The actual tooth number is, however, unclear as the empty alveoli are filled with matrix. The lateral portions of the dentaries bear numerous small foramina. Deep reception pits are present in the midsections of the dentary rami and at about the same level the surangulodentary groove starts on each side. The surangulodentary groove is positioned somewhat dorsal to the dorsoventral midline and extends to the surangular. A vertical zigzag-shaped posterior dentary-surangular suture is visible in both rami. Ventrally the slightly oblique angular suture starts at about the level of the anterior end of the jugal. A long ventral splenial contact is also visible in the rear part of both dentaries.

Coronoid. The coronoid is laterally exposed at the dorsal end of the rounded coronoid process in the right mandibular ramus. It is placed dorsal to the surangular that forms the remainder of the coronoid process (Figure 3 ).

Surangular. The surangular contacts the dentary via a zigzag-shaped suture near the level of the last preserved maxillary tooth (Figure 3). The surangulodentary groove is very pronounced at the level of the orbit and fades out at the level of the postorbital. The surangular forms the posterodorsal part of the mandible and most of the coronoid process that is visible in the right mandibular ramus. At the dorsal side of the coronoid process a short lateral surangular-coronoid contact is visible. The surangular sutures to the angular ventrally over its entire length. A short posterior contact to the articular is present at the retroarticular process of which the surangular forms part of the dorsal side.

Angular. The angular is well visible in lateral view. It starts at about mid-length of the mandible (Figure 3 ) and forms the posteroventral demarcation of the mandible. The angular is longitudinally curved and becomes gradually higher posteriorly. It terminates at the rear end of the retroarticular process of which it forms the ventral side. Anteriorly each angular contacts the dentary and dorsally a long, curved suture to the surangular is formed. Posterodorsally a short angular-articular contact is visible at the retroarticular process of which the angular forms the ventral part. Medially a contact to the splenials is visible.

Articular. The articulars are partly exposed on both sides (Figure 3). Their lateral contribution is minor as they only form the posterodorsal part of the retroarticular process. Each articular sutures to the surangular anteriorly and the angular ventrally. Hyoid. Both hyoids are preserved adjacent to the posterior-most part of the mandible (Figure 3). They are elongate, curved elements with a dorsoventrally expanded and transversely flattened posterior end. The latter is more dorsoventrally expanded than the anterior end.

Dentition. The dentition is slightly heterodont. All teeth are mediolaterally compressed giving them an oval cross-section, with pointed apices and no evidence of macrowear patterns (Figure 4A). The tooth crowns are all single-cusped and have no accessory cusps or cingula. The surface enamel is smooth, lacking apicobasally aligned ridges or any other macroscopic pattern. Faint carinae are present along the mesial and distal margins.

Scleral ring. The scleral ring of the left body side is well-preserved (Figure 4B). It consists of two asymmetrical portions, a larger dorsal and a smaller ventral one. The asymmetry might how- 


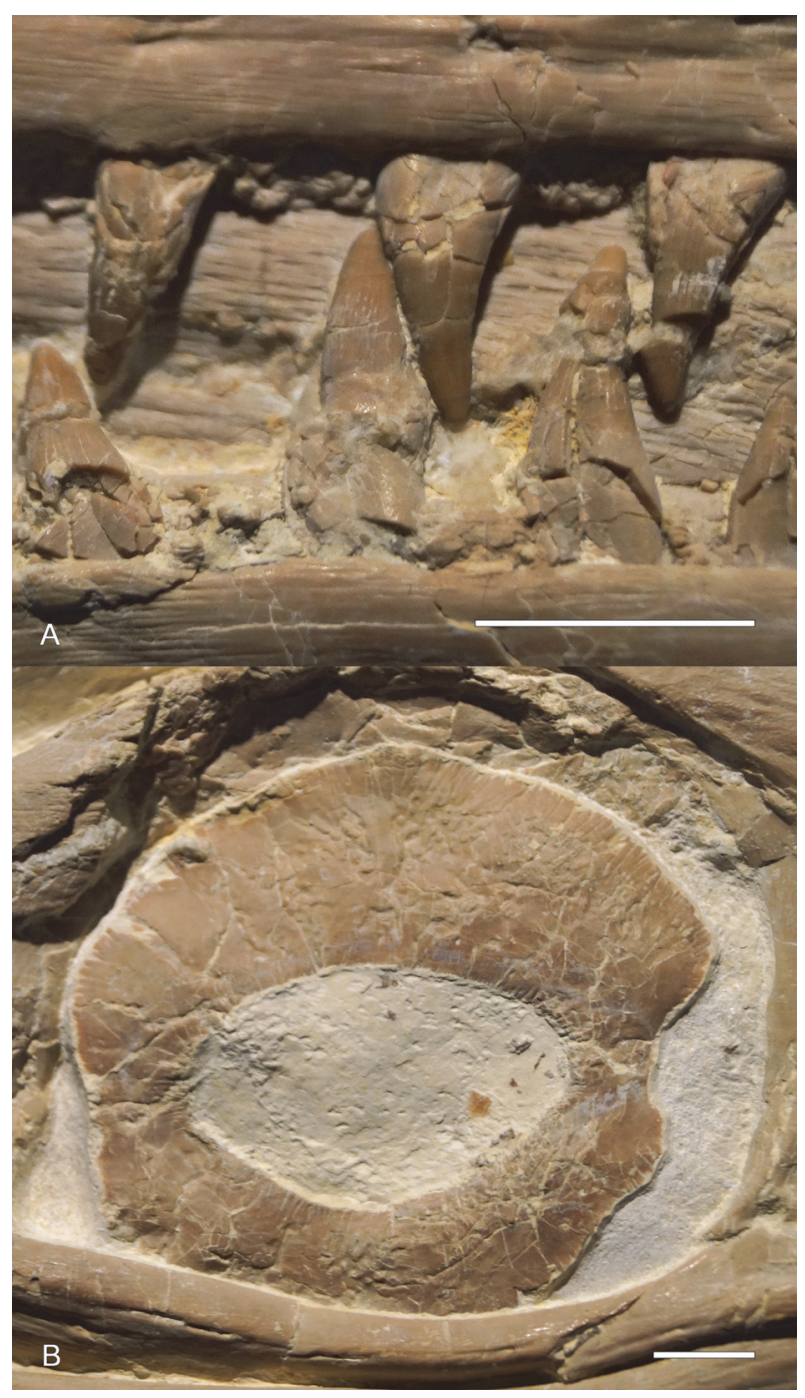

FIGURE 4. Cricosaurus albersdoerferi sp. nov. (BMMSBK 1-2) holotype, late Kimmeridgian of Painten (Southern Germany). Close-ups of the dentition (A) and scleral ring (B). Scale bars equal $10 \mathrm{~mm}$.

ever, to some extent, be a preservational artefact. Part of the ventral side of the scleral ring is obscured by the jugal. The scleral ring is narrowest at the anterior and posterior intersections of the two parts. The orbital opening in the center of the ring has an elongated oval shape.

Atlas-axis vertebrae and ribs. The atlas-axis complex is exposed in lateral view. However, large parts, especially of the atlas, are obscured by other bones (Figure 5A). Only the atlas postzygapophysis is well visible as a strap-shaped, posterodorsally oblique element that terminates at the level of the axis prezygapophysis. The axis centrum is also partly obscured but the lateroventrally protruding axis diapophysis is exposed. There are no remnants of the atlas rib in BMMS-BK 1-2, but an elon- gate fragment posteroventral to the axis centrum could be part of the axis rib. The axis postzygapophysis exceeds the level of the axis centrum posteriorly, but is otherwise obscured by the prezygapophysis of the third cervical vertebra. The neural spine of the atlas-axis complex has a rectangular shape, being anteroposteriorly elongate and dorsoventrally narrow. The dorsal side seems slightly undulating. The posterior margin between the posterodorsal point of the neural spine, and the axis postzygapophysis is concave in shape.

Postaxial cervical vertebrae and ribs. Four articulated postaxial cervical vertebrae are exposed in lateral view in BMMS-BK 1-2 (Figure 5A) of which three are genuine whereas the fourth postaxial vertebra is largely reconstructed (see Appendix 4). The centra are quadratic, being about as long as high. The dorsally placed, ventrolaterally protruding left diapophysis is exposed in the first to third postaxial cervical vertebrae. It is weakly keeled in the first postaxial cervical and shows a prominent, slightly posteriorly inclined lobe in the third postaxial vertebra. The parapophysis is only visible in the second and fourth postaxial cervical vertebra. It is placed ventrolaterally and protrudes ventrally in the second postaxial cervical whereas it has moved to the anterior articular surface rim and is placed anterolaterally, at about the centrum's mid-height, in the fourth postaxial cervical. The lateral side of the centrum between the dia- and parapophysis is slightly indented. The articular surfaces of the centra and zygapophyses are obscured. The pre- and postzygapophysis exceed the level of the centra with about half of their length. The prezygapophyses are slightly anterodorsally inclined and anteriorly rounded in lateral view. The neural spines are lower than the centra. They have a slightly convex anterior and dorsal edge and a concave posterior side.

The cervical ribs are detached from the centra and slightly overlay each other. The shafts of the first three pairs of ribs have concave anterior and posterior margins, leading to a constricted midshaft. The ventral rib portions have a reduced anterior process and an elongated, slightly posterodorsally curved and pointed posterior process. The latter is slender in the first post-axial cervical rib and higher and more prominent in the third post-axial cervical rib. The ribs of the fourth postaxial cervical vertebra are clearly more elongated, resembling the shape of the dorsal ribs. But their proximal portions are either embedded or reconstructed. 


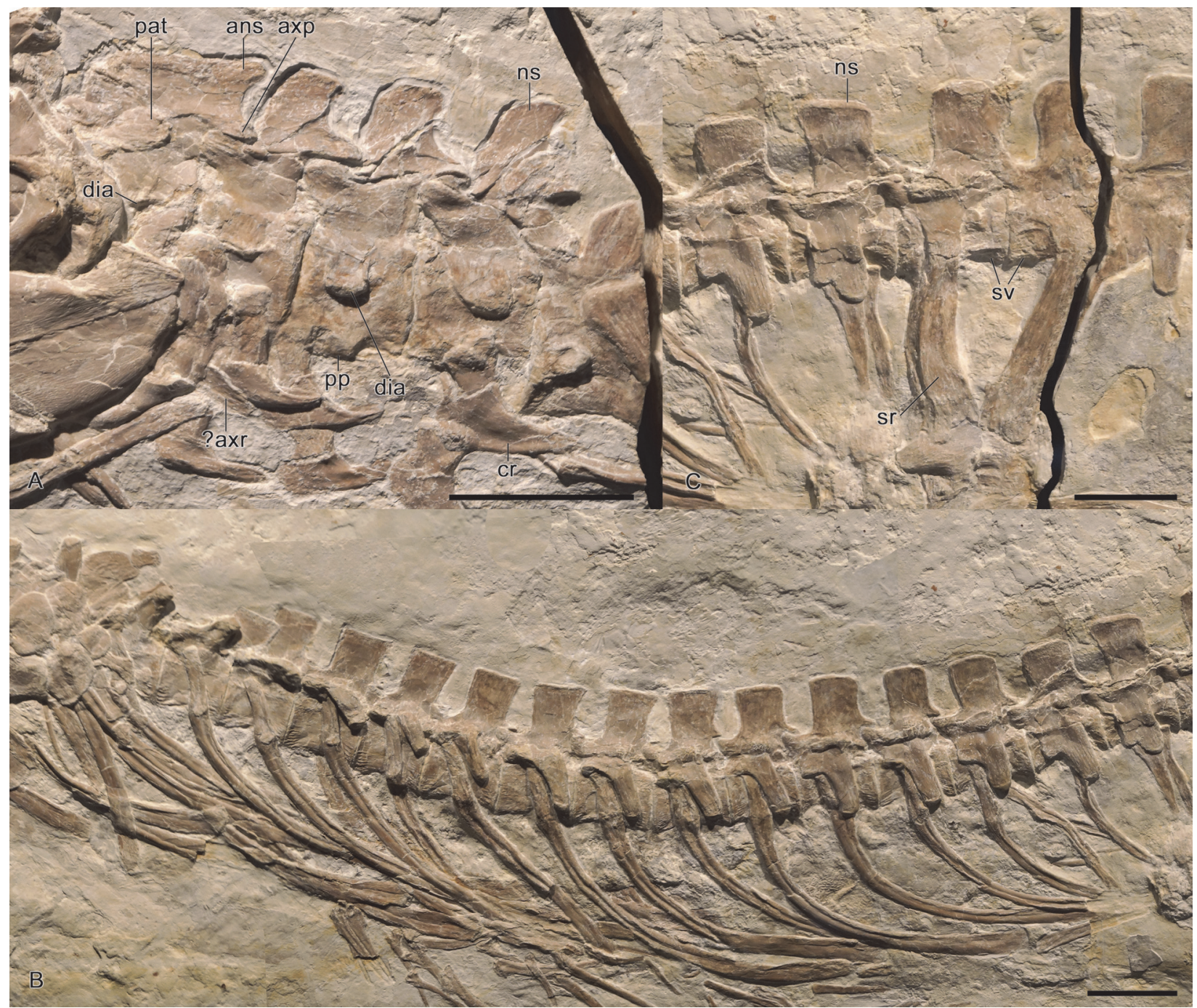

FIGURE 5. Cricosaurus albersdoerferi sp. nov. (BMMS-BK 1-2) holotype, late Kimmeridgian of Painten (Southern Germany). Cervical (A); dorsal (B) and sacral vertebrae (C) in lateral view. Abbreviations: ans, axis neural spine; axp, axis postzygapophysis; axr, axis rib; cr, cervical rib; dia, diapophysis; ns, neural spine; pat, postzygapophysis of atlas; pp, parapophysis; sr, sacral rib; sv, sacral vertebra. Scale bars equal $30 \mathrm{~mm}$.

Dorsal vertebrae and ribs. An articulated series of 15 presacral vertebrae can clearly be identified as dorsal vertebrae (Figure 5B). Four vertebrae at the cervico-dorsal transition are obscured by pectoral girdle elements so the actual number of dorsal vertebrae is probably slightly higher. All vertebrae are exposed in lateral view. The centra are elongated and longer than high in which the centra become slightly longer posteriorly. Distinct lateral striations are present adjacent to the articular surfaces of the centra. The ventral sides of the centra are concave in lateral view. The transverse processes are posterolaterally inclined in the anterior dorsal vertebrae, but they are mostly broken off, displaying their dorsal sides. While all transverse processes have a straight posterior edge the shape of the anterior edges changes along the series. In the anterior half of the dorsal vertebral column the anterior edge is concave while it becomes more angled in the posterior ones. At the same time the medial portion of the transverse processes become more plate-like and wider transversely towards posterior so that a flat medial platform and an elongated lateral process is formed. In the last dorsal vertebrae, the medial platform is very prominent and occupies most of the width of the transverse processes. The zygapophyses are only visible in some posterior dorsal vertebrae. They only slightly exceed the level of the centra with their longitudinal dimensions. The neural spines are largely covered by plaster or they are reconstructed, but those that are genuine have a 
rectangular shape, being about as long as high with almost straight anterior, posterior, and dorsal margins.

The dorsal ribs are placed adjacent to the centra, but the rib heads are largely obscured by the transverse processes. The rib heads are exposed in the anterior dorsal vertebrae showing a slender, slightly offset proximal portion and a circular protuberance for the articulation with the diapophyses. The remainder of each rib is slender and bears a prominent fossa along the posterior side that flares in the distal portion of the rib. The latter is slightly anteroposteriorly expanded and transversely flattened.

Gastralia. Several curved, strap-shaped gastralia of the disarticulated gastric basket are present adjacent to the dorsal ribs. Some are, however, reconstructed or obscured by plaster.

Sacral vertebrae and ribs. Two complete sacral vertebrae are present, but a crack extends alongside the posterior portion of the second sacral vertebra and rib (Figure 5C). The vertebral centra are longer than high. Laterally they are largely obscured by the sacral ribs, but the exposed ventral sides of the centra are gently concave. As in the dorsal vertebrae the zygapophyses exceed the level of the centra at the longitudinal plane. The neural spines are placed more posteriorly than those in the dorsal vertebrae. The anterior edges are straight, and the dorsal ones are slightly convex. The posterior side of the first sacral neural spine is gently convex dorsally and concave on its ventral side. The neural spine of the second sacral vertebra is damaged. The sacral ribs are massive rod-shaped elements which are pushed downwards so that their dorsal aspects are exposed in lateral view. The midsections of the sacral ribs are partly reconstructed or covered by plaster. In the first sacral vertebra the left and right ribs are visible which overlap each other. The first sacral rib is placed in the anterior half of the centrum, the second rib meets the centrum posteriorly. Both ribs together form a V-shaped structure in which the undulated first sacral rib only has a slightly posteriorly curved distal portion, whereas the straight second sacral rib is inclined anteriorly. The distal portions of the sacral ribs are obscured.

Caudal vertebrae and ribs. An articulated caudal series is preserved. The nine distal-most caudals are reconstructed, but 33 caudals are genuine. All centra are exposed in lateral view and have a slightly concave ventral side (Figure 5A). The transverse processes in the proximal-most caudal vertebrae are broken off and obscure the lateral surfaces of the centra, but they are evident in 14 vertebrae from the proximal part of the tail. In these vertebrae the transverse processes are placed in about the dorsoventral midsection of the centra. The lateral surfaces of the centra are slightly convex in the remaining vertebrae and almost flat in the distal caudals. The ventral sides of the centra are concave. In some of the proximal caudal vertebrae the posteroventral sides of the centra protrude ventrally to meet the hemapophyses. The zygapophyses are small, and they only barely exceed the level of the centra longitudinally. The neural spines of the proximal-most caudals are covered by plaster or they have been reconstructed, but those in the preflexural caudals 9-15 and 17-22 are genuine (see Appendix 4). The neural spines of caudals $9-15$ bear a pronounced, pointed anterodorsal process that is placed dorsal to the spines mid-height. This process becomes weaker posteriorly and is absent in the $17^{\text {th }}$ caudal. In the $9^{\text {th }}$ and $10^{\text {th }}$ caudal vertebra the neural spine process is very prominent and placed somewhat ventral to the mid-height of the spines. The anterior surface of the neural spine is strongly concave dorsal to this process. The neural spine processes are dorsally directed and noticeably smaller in the succeeding caudal vertebrae. The neural spines from the $9^{\text {th }}$ caudal vertebra onwards are posterodorsally inclined, in which the inclination becomes gradually stronger towards the tail bend.

The dorsal margins of the neural spines are convex in all vertebrae to the tail bend. The hemapophyses are largely reconstructed or they are covered by plaster, but some genuine hemapophyses are preserved between the $11^{\text {th }}$ and $14^{\text {th }}$ caudal vertebrae. They are elongated rodlike elements with a flared, lobe-shaped ventral side. From the $17^{\text {th }}$ caudal vertebra onwards until the tail bend at the $26^{\text {th }}$ caudal vertebra, the hemapophyses are small rods.

While the morphology of the proximal and mid-caudal vertebrae remains more or less uniform, their shape changes at the tail-bend (Figure $6 \mathrm{~B})$. The $26^{\text {th }}$ caudal vertebra becomes stouter in which the anterior and posterior articulation surface are obliquely angled. The anterior articulation surface is posteroventrally inclined, the posterior one anteroventrally, given the centrum a slight triangular shape. The prezygapophysis is anteriorly oriented, and the neural spine strongly faces posterodorsally, being about as high as the centrum. In the $27^{\text {th }}$ caudal vertebra, the articular surfaces of the centrum are less inclined. The ventral side of the centrum is strongly concave with the 


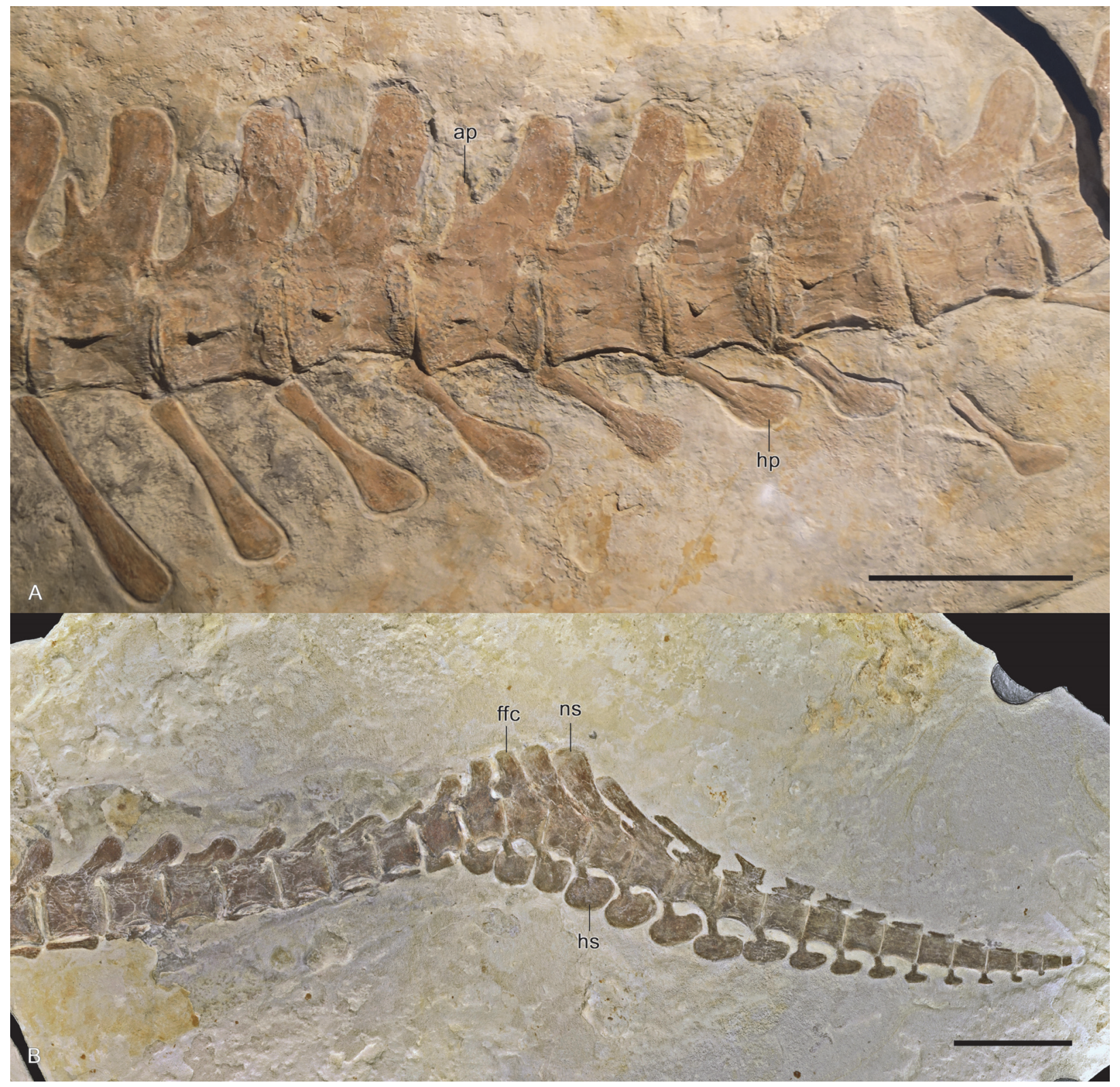

FIGURE 6. Cricosaurus albersdoerferi sp. nov. (BMMS-BK 1-2) holotype, late Kimmeridgian of Painten (Southern Germany). Caudal vertebrae in lateral view. (A) proximal caudals, (B) distal caudal series and tail bend. Abbreviations: ap, anterior process; ffc, first flexural caudal vertebra; hp, hemapophysis; hs, hemapophyseal lobe; ns, neural spine. Scale bars equal $50 \mathrm{~mm}$.

neural spine facing only slightly posterodorsally and being about as high as the centrum. The prezygapophysis likewise faces anteriorly. In the $28^{\text {th }}$ caudal vertebra the posteroventral side of the centrum is strongly ventrally inflected, the prezygapophysis is higher than in the adjacent vertebrae and the neural spine faces anteriorly.

In the $29^{\text {th }}$ caudal vertebra the anteroventral and posteroventral sides of the centrum are placed at the same level, but the hemapophyseal facets are strongly inclined. The neural spine is placed anterodorsally. It is strongly anteriorly inclined and almost twice as high as the caudal centrum. The same morphology applies for the $30^{\text {th }}$ caudal vertebra where the neural spine is even more elongated and the postzygapophysis is reduced. In the $31^{\text {st }}$ caudal vertebra the centrum is similar but more elongated. The prezygapophysis is more expanded anteriorly and reaches to the midsection of the $30^{\text {th }}$ caudal. The neural spine is even more anteriorly inclined, though partly reconstructed, but noticeably smaller than in the $29^{\text {th }}$ and $30^{\text {th }}$ caudal 
vertebra. The surface between the prezygapophysis and neural spine is prominently excavated. The $32^{\text {nd }}$ caudal vertebra is reconstructed or covered by plaster.

The morphology of the caudal centra 33 and 34 is similar with them being slightly rectangular and having a gently concave ventral side. The neural spines are noticeably smaller than in the previous vertebrae, but it is unclear whether they are completely preserved.

The hemapophyses at the tail bend are largely reconstructed or covered by plaster, but those that are clearly genuine have a peculiar morphology. Between the $25^{\text {th }}$ and $26^{\text {th }}$ caudal vertebrae the hemapophyses are noticeably broader than in the previous vertebrae. The hemapophysis between the $26^{\text {th }}$ and $27^{\text {th }}$ caudal vertebrae the hemapophysis is very prominent, almost as high as the centrum, and fan-shaped with a convex ventral side. That between caudal vertebrae 27 and 28 is reconstructed or covered by plaster, but the hemapophysis between the $28^{\text {th }}$ and $29^{\text {th }}$ caudal vertebrae is more quadratic, has almost straight anterior and posterior sides and a prominent anterodorsally placed shaft for the articular on with the centra. The hemapophyses between caudal vertebrae 29 and 33 are reconstructed. The one between caudal vertebrae 33 and 34 has an elongate oval shape.

Scapula. Part of what appears to be the scapula is preserved dorsal to the coracoids, but the preservation does not allow a more detailed description (Figure 7A).

Coracoid. The coracoids are preserved next to each other (Figure 7A). They are flat elements having concave anterior and posterior edges in which the anterior edge is stronger concave than the posterior one, leading to a constricted midsection. The proximal and distal portions are expanded and have convex edges. A small, circular, proximally placed coracoid foramen is evident.

Humerus. Both humeri are preserved (Figure 7A). The right one is visible in ventral aspect, the left one in dorsal view. The humeri are stout, sub-rectangular elements. The anteroproximally placed deltopectoral crest is visible as a rounded flange in the right humerus. The humerus head is rounded but it is not well preserved in the right humerus and obscured in the left one. Ventrally a ridge is formed at the right humerus that extends posterodistally, from the midsection of the proximal end to the posterior midshaft. This ridge might, however, be artificial. The distal end is flat and narrower than the proximal one.
Radius/Ulna. The epipodials are preserved in both fore-limbs (Figure 7A). They are circular elements of about equal size. However, as both fore-limbs are disarticulated it cannot be judged with certainty which of these elements represents the radius and the ulna.

Carpal elements. Several elements of the disarticulated carpals are preserved but they are largely obscured by other bones (Figure 7A). The roundish left radiale appears to be partly visible adjacent to supposed radius. The left ulnare seems to be obscured by metacarpals. Radiale and ulnare of the right fore-limb are poorly preserved, but likewise show a circular appearance.

Metacarpals. Four metacarpal elements of the left fore-limb are preserved in a row (Figure 7A). The first metacarpal is crescent-shaped with a semi-circular anterior edge and a slightly concave posterior one. It is larger than the other metacarpal elements. Metacarpals 2-4 are elongated elements of equal length with slightly expanded proximal and distal ends. The fifth metacarpal appears to be obscured by the matacarpal 3 and 4 .

Phalanges (forelimb). Only one hourglass-like phalanx is clearly genuine (Figure 7A), the other phalanges are either covered by plaster or they are reconstructed (see Appendix 4). The phalanx has expanded proximal and distal portions and a constricted mid-section. The thickened appearance indicates that this is a phalanx from the first digit.

Ilium. Only the left ilium is visible, but largely obscured by the left femur. It is still aligned to the sacral ribs and has a short protruding anterior process (Figure 7B).

Pubis. The distal part of the left pubis is exposed, whereas the proximal portion is not well visible (Figure 7B). The distal pubis is fan-like expanded and narrows proximally. Its distal edge is convex, and the anterior and posterior sides are concave.

Ischium. The left ischium is damaged and largely obscured by the femora. Only the broken posterior portion is visible. The fragment has slightly convex dorsal and posterior edges. Posteroventrally a prominent, ventrally protruding lobe-shaped portion is evident, formed by the posterior and ventral edge of the ischium.

Femur. Both femora are preserved (Figure 7B). They are elongated, sigmoidally curved elements which lack a fourth trochanter (sensu stricto). The proximal femoral end is slightly wider than the distal one. Each femur is narrowest in the midshaft region. Adjacent to the proximal end, some proximodistally extending striations are present. Similar, but less distinct striations are also evident at the 


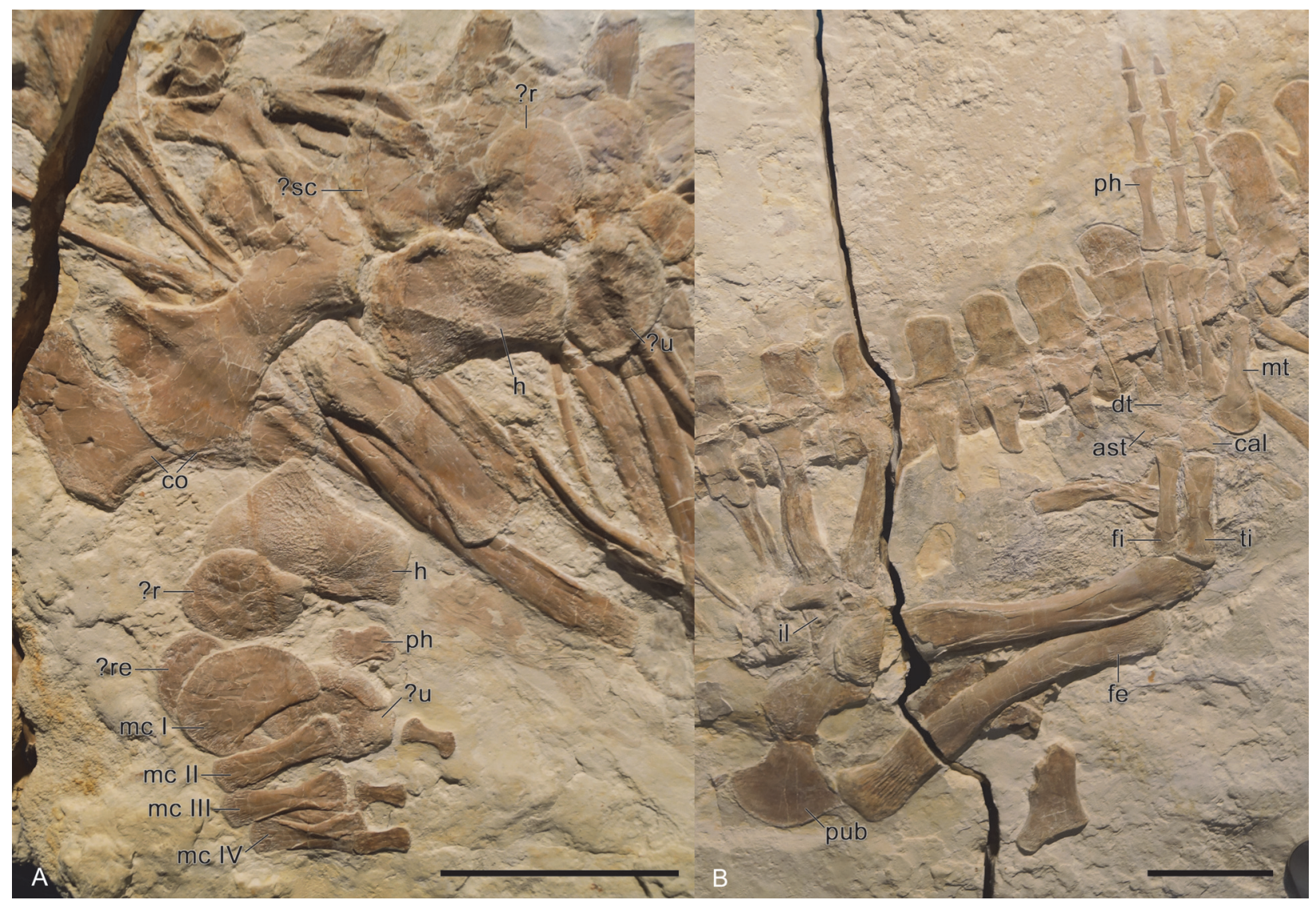

FIGURE 7. Cricosaurus albersdoerferi sp. nov. (BMMS-BK 1-2) holotype, late Kimmeridgian of Painten (Southern Germany). Limbs and girdle elements. (A) front limbs and pectoral girdle, (B) hind limbs and pelvis. Abbreviations: ast, astragalus; cal, calcaneum; co, coracoid; dt, distal tarsal; fe, femur; fi, fibula; $h$, humerus; il, ilium; mc, metacarpal; mt, metatarsal; ph, phalanx; pub, pubis; r, radius; re, radiale; sc, scapula; ti, tibia; u, ulna. Scale bars equal 50 $\mathrm{mm}$.

distal end. The proximal heads of both femora bear two inclined facets, which are angled to one another and form a broad tip at their intersection.

Tibia. The left tibia is preserved in original alignment with the fibula and femur (Figure 7B). It is a rectangular element with slightly concave anterior and posterior edges. The tibia is shorter than the fibula but more anteroposteriorly expanded. The proximal and distal sides are flattened. Distally the tibia contacts the calcaneum.

Fibula. The elongate left fibula is preserved in original alignment with the tibia and femur (Figure 7B). It is longer than the tibia but only about half as wide. The anterior and posterior sides of the fibula are slightly concave, and the proximal and distal edges are gently convex. Distally the fibula has a short anterior contact to the calcaneum and a long one to the astragalus.

Tarsal elements. The tarsal elements are preserved in original alignment but they are less well preserved than the surrounding elements (Figure
7B). The anteriorly placed calcaneum is a sub-circular element that is slightly smaller than the astragalus. It contacts the tibia proximally, the fibula posteroproximally and the astragalus posteriorly. A long anterodistal contact to the first metacarpal and a shorter distal one to distal tarsal 3 is observable. The astragalus is slightly larger than the calcaneum. It contacts the fibula proximally, the calcaneum anteriorly and the distal tarsal 4 distally. The distal tarsal 3 is placed distal to the calcaneum and is about equal in size to the distal tarsal 4 that is placed below the astragalus. The distal tarsals have been slightly shifted posteriorly, but it appears that distal tarsal 3 originally contacted metatarsals 1-3, whereas distal tarsal 4 contacted metatarsal 4 and 5 .

Metatarsals. The metatarsals are preserved in original alignment with the tarsals (Figure 7B). The first metatarsal is placed more proximally than the other metatarsal elements and has a flared anteroposteriorly expanded distal end that contacts the 
calcaneum. Metatarsals 2-4 are elongated, rodshaped elements of about equal length. They have expanded proximal and distal ends and a slightly constricted midsection. The fifth metatarsal is a sub-triangular bone that is much smaller than the other metatarsal elements.

Phalanges (hind limb). All phalanges except for the terminal ones are elongated with anteroposteriorly expanded proximal and distal ends and a slightly constricted midsection (Figure 7B). The terminal phalanx that is genuine in digit two, is pointed, and the shortest element in the hind-limb. The phalanges of the first digit are partly disarticulated but those of the second to fourth digit are largely well preserved and in original alignment, although partly covered by plaster. The first digit bears two phalanges. The proximal one is partly damaged, but it is clearly smaller than the proximal phalanges of the other digits. The second phalanx of the first digit is pointed and about half as long as the first one. The second digit has three phalanges the proximal one of which is about twice as long as the second phalanx of the second digit. The third digit has four phalanges, in which the terminal one is reconstructed or covered by plaster. The proximal-most phalanx is larger than the first phalanx of the second digit and is also more expanded proximally. It is likewise about twice as long as the second phalanx of the third digit. The latter is about twice as long as the third one. The fourth digit likewise consists of four phalanges in which only the first and second are genuine. The proximal-most one has about the length of the same phalanx in the third digit, but it is broader than all other proximal-most phalanges. The second phalanx of the fourth digit again is about half as long as the first one but also shorter than the same phalanx of the third digit.

Soft tissue. Remnants of the integument are preserved. The soft tissue, however, will be described in a separate publication.

\section{PHYLOGENETIC ANALYSIS}

A phylogenetic analysis was conducted to assess the evolutionary relationships of BMMS-BK 1-2 within Thalattosuchia. The dataset employed forms part of the ongoing Crocodylomorph SuperMatrix Project and is the phylogenetic framework for the Edinburgh-based CrocTransition Project. This dataset (referred to as the Hastings + Young matrix, or HY matrix) is continually being revised (e.g., Ristevski et al., 2018; Ösi et al., 2018, Foffa et al. 2019; Sachs et al. 2019; Young et al. 2020a, 2020b; Johnson et al. 2020), and herein we revise the most recent version in Young et al. (2020b). This revision consisted of the following: we added seven new craniomandibular pneumatic characters, moved a character from the braincase region of the dataset to the pneumaticity section, revised the metriorhynchid salt gland character, altered character 440 from a binary to an ordered multistate character, and removed the tail fluke character that was apomorphic for Cricosaurus albersdoerferi as that region of the tail is reconstructed. All character changes can be found in Appendix 5, the matrix is found in Appendix 6. We also removed two operational taxonomic units, the two Cuban metriorhynchine metriorhynchids, as they are currently being re-described, and their character scores have changed. We also corrected some scoring errors for $C$. lithographicus and $C$. schroederi, and added the two recently established Cricosaurus species, C. puelchorum Herrera et al., 2021b, and C. rauhuti Herrera et al. 2021a.

This resulted in the current iteration of the HY matrix containing a total of 179 OTUs scored for 580 characters. Forty-seven characters are morphoclines and were treated as ordered $(6,7,8,11$, $28,41,44,49,59,77,78,86,91,97,100,101$, $108,127,151,181,210,224,226,227,238,251$, $264,278,299,310,343,345,364,420,439,446$, $450,458,468,472,521,524,538,539,541,542$, 555). Batrachotomus kupferzellensis was used as the outgroup taxon.

The phylogenetic analyses were conducted following the methodology implemented using freeware TNT v1.5-beta, Willi Hennig Society Edition (Goloboff et al., 2008, Goloboff and Catalano, 2016; programme has been made available with the sponsorship of the Willi Hennig Society). We used the same search protocol as that outlined in Young et al. (2020a), using their EIW.tnt script to run an equal weights' analysis and a series of extended implied weighting analyses (Goloboff, 2014) varying in their $k$ value (piwe $=1$, piwe $=3$, piwe $=7$, piwe $=10$, piwe $=15$, piwe $=20$, and piwe $=50$ ). The script also runs two types of nodal support analyses, a heuristic absolute Bremer support analysis and a symmetric resample analysis. See Young et al. (2020a) for their description of how the script works and for full details of the search protocol.

Overall, the strict consensus topology recovered here (Figure 8; Table 1) is very similar to the one presented in Young et al. (2020a, 2020b) and Herrera et al. (2021a, 2021b). Note, herein we will solely focus on the internal relationships of Metriorhynchinae. The major difference between our 

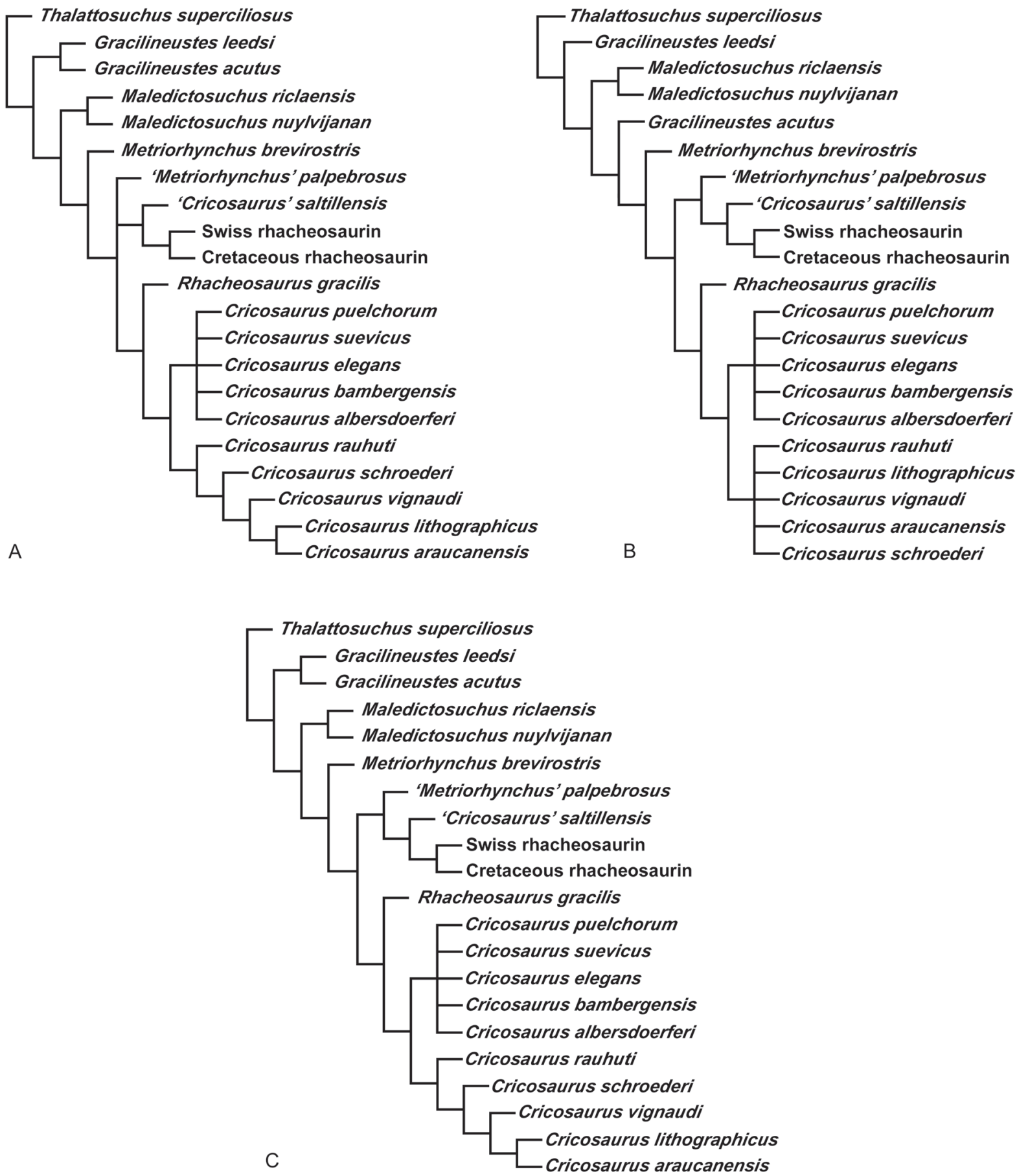

FIGURE 8. Strict consensus topologies of Metriorhynchinae found in the parsimony analyses. A, unweighted topology; $B$, strongly down-weighted topology $(k=1)$; , all other weighting analyses topology $(k=3,7,10,20$, and 50$)$. 
TABLE 1. Descriptive statistics of the fundamental cladograms from the parsimony analyses. ${ }^{*}=$ maximum hold of 20,000 most parsimonious cladograms (MPCs) was hit.

\begin{tabular}{cccccccc}
\hline $\mathbf{K}$ & \#MPCs & Length & Fit & Cl & RI & RC & HI \\
\hline- & $*$ & 2188 & - & 0.387 & 0.850 & 0.329 & 0.613 \\
1 & 315 & 2115 & 200.721 & 0.388 & 0.850 & 0.330 & 0.612 \\
3 & 45 & 2106 & 131.201 & 0.389 & 0.851 & 0.331 & 0.611 \\
7 & 45 & 2097 & 84.562 & 0.391 & 0.852 & 0.333 & 0.609 \\
10 & 45 & 2094 & 68.250 & 0.392 & 0.852 & 0.334 & 0.608 \\
15 & 45 & 2077 & 52.301 & 0.395 & 0.854 & 0.337 & 0.605 \\
20 & 45 & 2082 & 42.676 & 0.394 & 0.854 & 0.336 & 0.606 \\
50 & 45 & 2080 & 20.743 & 0.394 & 0.854 & 0.337 & 0.606 \\
\hline
\end{tabular}

results and those of Young et al. (2020b) are the removal of the two Cuban metriorhynchine metriorhynchids. Overall, their removal has led to more consistent results for the internal relationships of Metriorhynchinae, with three differing topologies recovered. All share the following basic structure, from the base of Metriorhynchinae there is: Thalattosuchus superciliosus, followed by Gracilineustes spp., Maledictosuchus spp., and a sister group relationship between Metriorhynchus brevirostris and Rhacheosaurini. Within Rhacheosaurini there is a split between the Rhacheosaurus + Cricosaurus sensu stricto subclade and a subclade of consisting of 'Metriorhynchus' palpebrosus, 'Cricosaurus' saltillensis, the 'Swiss rhacheosaurin' re-described by Young et al. (2020a) and the diagnostic Early Cretaceous specimen previously referred to Enaliosuchus macrospondylus (see Sachs et al., 2020). Within Cricosaurus there are two subclades: 'subclade A' (sensu Herrera et al., 2021b) consists of C. bambergensis, C. albersdoerferi, $C$. suevicus and C. elegans from the Kimmeridgian-Tithonian of Southern Germany, and $C$. puelchorum from the Berriasian of Argentina; while 'subclade B' (sensu Herrera et al., 2021b) consists of $C$. rauhuti from the Tithonian of Germany, $C$. schroederi from the Valanginian of Germany, $C$. vignaudi from the Tithonian of Mexico, and $C$. araucanensis and $C$. lithographicus from the Tithonian of Argentina.

In the equal weight strict consensus topology (Figure 8A, Appendix 7), the unique arrangements are: 'Metriorhynchus' palpebrosus is recovered in a polytomy with Rhacheosaurus + Cricosaurus sensu stricto, and the clade consisting of 'Cricosaurus' saltillensis and unnamed specimens from Switzerland and France. Cricosaurus 'subclade B' is fully resolved, with $C$. rauhuti as the basal most taxon, C. schroederi is the sister taxon to the South American species, with $C$. vignaudi being the sister taxon to the two Argentinian species (C. araucanensis and C. lithographicus).

In the strongly down-weighted strict consensus topology $(\mathrm{k}=1)$ (Figure 8B, Appendix 8), 'Metriorhynchus' palpebrosus is now the basalmost member of the saltillensis-Swiss-Cretaceous clade. Cricosaurus 'subclade B' is now a polytomy. Curiously, Gracilineustes acutus is no longer recovered as the sister taxon to Gr. leedsi; instead, it is in a more derived position, between Maledictosuchus spp. and Me. brevirostris. This is the first time a HY dataset analyses has failed to recover a monophyletic Gracilineustes.

All other weighted strict consensus topologies $(\mathrm{k}=3,7,10,15,20,50)$ (Figure 8C, Appendix 9) find identical metriorhynchine internal relationships. Gracilineustes is monophyletic, 'Metriorhynchus' palpebrosus is the basal-most member of the saltillensis-Swiss-Cretaceous clade, and the South American-Cretaceous Cricosaurus subclade is fully resolved.

The character changes made herein has had no impact on the position of Cricosaurus albersdoerferi (BMMS-BK 1-2), previously referred to as 'the Solnhofen Cricosaurus' in the phylogenetic analyses of Young et al. (2020a, 2020b). It is consistently recovered within Cricosaurus 'subclade A'. As with Herrera et al. (2021a, 2021b) Cricosaurus 'subclade $A$ ' is herein recovered as a polytomy, regardless of weighting regime used. This is due to: (1) C. elegans and C. puelchorum not having known postcrania, and thus lacking the relevant character scores, and (2) that we changed the termination of the maxillary tooth-row relative to the orbit anterior margin character scores for three members of 'subclade $A$ ' (C. albersdoerferi, $C$. suevicus, and C. elegans were re-scored as a '?'). We did the latter, as we agree with Herrera et al. (2021a) that we cannot be sure where the maxillary tooth-row ends. The maximum agreement subtrees remove both $C$. elegans and C. puelchorum, 
and they consistently recover a resolved 'subclade $A^{\prime}$, with $C$. bambergensis being the sister taxon to $C$. albersdoerferi $+C$. suevicus.

\section{Southern German Cricosaurus Species Complex}

The question whether there were one or multiple species of Cricosaurus species from the late Kimmeridgian-early Tithonian of Southern Germany, or just one, has been discussed in the literature. Andrade et al. (2010) noted that there was a potential synonymy between $C$. elegans and $C$. suevicus and stated that all specimens referred to C. suevicus at that time were from Malm Zeta 1 (upper Kimmeridgian), while those referred to $C$. elegans were known from Malm Zeta 2-3 (lower Tithonian). As such, there was a question as to the validity of the specific separation, or whether these where chronospecies or an anagenic lineage.

The recent description of a new species, Cricosaurus bambergensis (NKMB-P-Watt14/274) from the upper Kimmeridgian by Sachs et al. (2019) re-opened this debate. They discovered a unique palatal morphotype in the specimen that has a tail fluke morphologically intermediate between more basal metriorhynchines and $C$. suevicus. Moreover, the phylogenetic analysis of Sachs et al. (2019) united C. elegans, C. suevicus, and $C$. bambergensis into an unresolved clade. It was the first phylogenetic analysis to unite the Southern German Cricosaurus species into a subclade. Sachs et al. (2019) could not rule out that these three species represent an anagenetic lineage in which the tail fluke became progressively steeper with an increase in soft tissue attachment surface area over time. The unusual palatal morphology of C. bambergensis (NKMB-P-Watt14/ 274) could suggest this is not the case; however, many German Cricosaurus specimens do not preserve the ventral surface of the palate.

Furthermore, the recent description of $C$. rauhuti from the lower Tithonian of Germany by Herrera et al. (2021a) provides further evidence that not all the Cricosaurus material from the Solnhofen Archipelago is conspecific. Interestingly, the newly described species C. puelchorum from the Berriasian of Argentina was recovered in a polytomy with the members of the 'Southern German subclade' (see Herrera et al., 2021b; and our results herein). Therein Herrera et al. (2021b) designated the 'Southern German' group along with $C$. puelchorum 'subclade A', with 'subclade B' composed of the Mexican and Argentinean species, along with $C$. rauhuti from the Tithonian of Ger- many and C. schroederi from the Valanginian of Germany.

Herein we show that there was morphological variation between the German species of 'subclade $A^{\prime}$ from different ammonite zones, and species from the same ammonite subzone. Note, however, that there is no evidence for sympatry (unless both C. elegans and C. medius are valid taxa). In fact, the extensive cranial and postcranial differences between these taxa allows us to revise their diagnoses (see below) with the possible exclusion of $C$. elegans and C. medius (but see below for why we provisionally retain these species as being distinct from $C$. suevicus). The geologically oldest species in 'subclade A', C. bambergensis, is only known from the 'Wattendorf lagoon', and the Aulacostephanus pseudomutabilis ammonite Zone (upper Kimmeridgian). Cranially, it differs from all other Southern German Cricosaurus specimens (Figure 9) in that: 1) the maxillary row clearly continues posteriorly past the anterior margin of the orbit (a thalattosuchian symplesiomorphy) and 2) palatines have a distinct midline ridge with paired depressions on either side (autapomorphy - but unknown for $C$. suevicus and $C$. albersdoerferi). The tail displacement unit (Figure 10) is also unique in $C$. bambergensis. The distal-most three preflexural vertebrae have neural spines that are oriented very strongly posteriorly, such that their posterior margins lie on top of the prezygapophyses of the posterior vertebra. The three vertebrae anterior to them have a similar morphology, but the neural spines look more like a 'regular' neural spine, albeit strongly oriented posteriorly. The tail fluke of $C$. bambergensis lacks the four synapomorphies shared by $C$. albersdoerferi and C. suevicus, retaining the following metriorhynchid symplesiomorphies: 1) the distal-most preflexural vertebra has a rod-like hemapophysis; 2) the proximal-most five or six flexural vertebrae have anteriorly oriented neural spines, but not strongly oriented anteriorly; 3 ) the flexural hemapophyses contact one another along their anterior-posterior margins; and 4) the distal-most postflexural hemapophyses return to a 'rod-like' morphology. Cricosaurus bambergensis also lacks the 'sub-rectangular' dorsal neural spines (with an almost flat dorsal margin) shared by $C$. albersdoerferi and $C$. suevicus.

Postcranially, nothing can be said for $C$. elegans and C. medius; however, C. suevicus (GPITPV-31381, SMNS 9808) and C. albersdoerferi (BMMS-BK 1-2) share four tail fluke synapomorphies: 1) the distal-most preflexural vertebra has a dorsoventrally deep hemapophysis, with a midline 


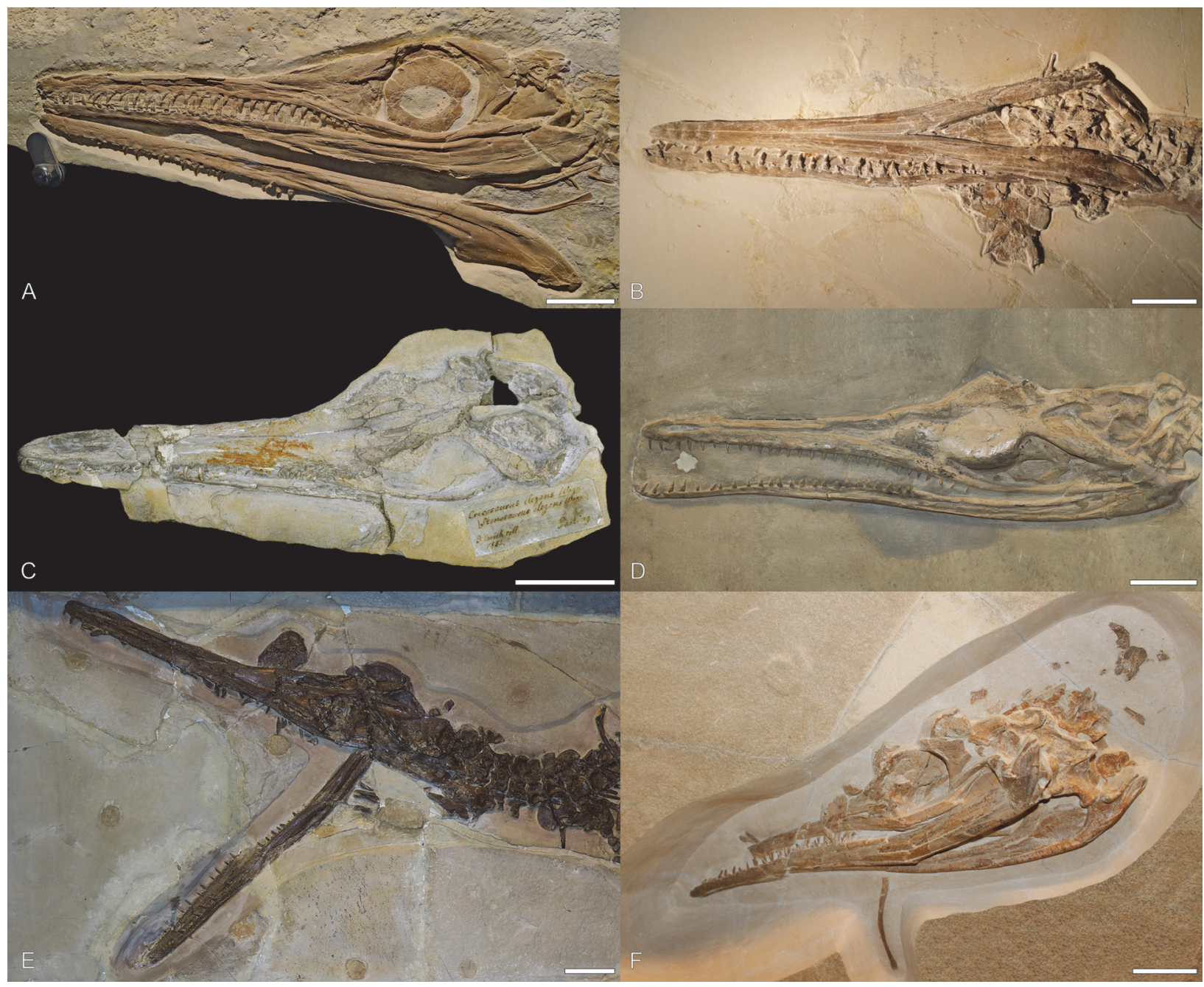

FIGURE 9. Comparison of crania of Late Jurassic Cricosaurus specimens from southern Germany. (A) BMMS-BK 1-2, holotype of Cricosaurus albersdoerferi sp. nov.; (B) NKMB-P-Watt14/274, holotype of Cricosaurus bambergensis; (C) SNSB-BSPG AS I 504, holotype of Cricosaurus elegans; (D) SMNS 9808, lectotype of Cricosaurus suevicus; (E) GPIT-PV-31381, referred specimen of Cricosaurus suevicus and (F) SMNS 7322, referred specimen of Cricosaurus suevicus. Scale bars equal $50 \mathrm{~mm}$.

flange (i.e., it does not have a rod-like hemapophysis as in C. bambergensis NKMB-P-Watt14/274 and Rhacheosaurus gracilis NHMUK PV R 3948); 2) the five or six proximal-most flexural vertebrae have strongly anteriorly oriented neural spines (much more so than $C$. bambergensis NKMB-PWatt14/274, R. gracilis NHMUK PV R 3948 and Thalattosuchus superciliosus GPIT-PV-31379); 3) the flexural hemapophyses contact one another along their posteroventral-anterodorsal margins (not their posterior-anterior margins as in C. bambergensis NKMB-P-Watt14/274, $R$. gracilis NHMUK PV R 3948 and T. superciliosus GPIT-PV31379); and 4) the distal-most postflexural hemapophyses retain their dorsoventrally deep profile (i.e., they do not return to a rod-like mor- phology, as in C. bambergensis NKMB-P-Watt14/ 274 and $R$. gracilis NHMUK PV R 3948). These two species also share the same unusual dorsal neural spine morphology.

Cricosaurus albersdoerferi and C. suevicus are known from the same ammonite subzone (Lithacoceras ulmense Subzone, Hybonoticeras beckeri Tethyian ammonite Zone), but not from the same lagoons. The lectotype and all referred specimens of Cricosaurus suevicus are only known from the 'Nusplingen lagoon' of Baden-Württemberg (Table 2), whereas C. albersdoerferi is only known from the 'Painten lagoon' of Bavaria.

Cricosaurus suevicus (Fraas, 1902; GPIT-PV31381, SMNS 9808, SMNS 90513) can be distinguished based on: 1) lack of pronounced, or regu- 


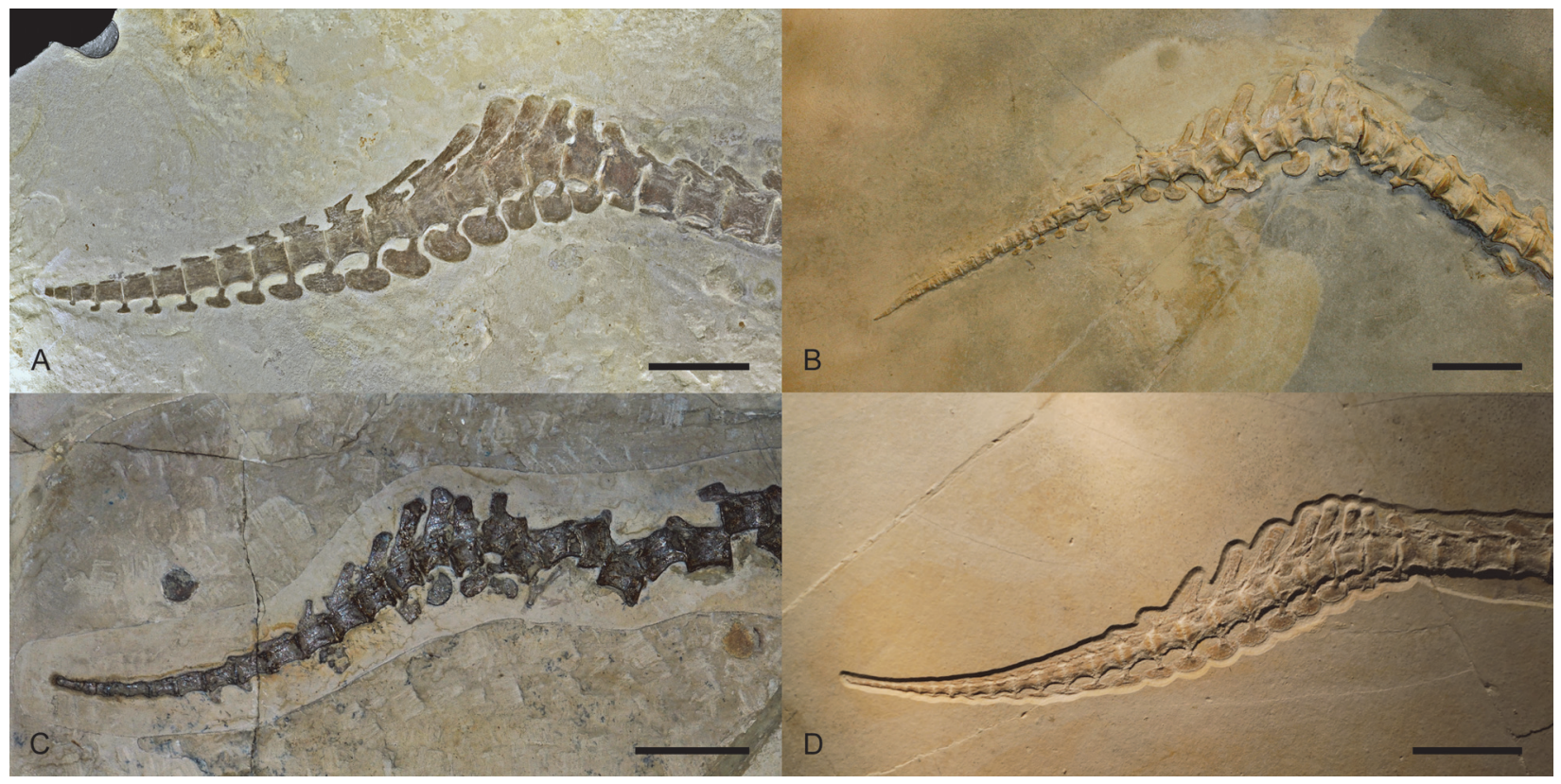

FIGURE 10. Comparison of tail bends of Late Jurassic Cricosaurus specimens from southern Germany. (A) BMMS-BK 1-2, holotype of Cricosaurus albersdoerferi sp. nov.; (B) SMNS 9808, lectotype of Cricosaurus suevicus; (C) GPIT-PV31381, referred specimen of Cricosaurus suevicus; (D) NKMB-P-Watt14/274, holotype of Cricosaurus bambergensis. No scale bars intended.

lar shallow, reception pits on the lateral margins of the middle maxilla and dentary (shared with C. elegans and C. medius); 2) the anterior-posterior margins of adjacent dorsal neural spines are in close proximity to one another (autapomorphy); 3) presence of 50 or more caudal vertebrae (symplesiomorphy), and 4) the composition of the tail displacement unit (autapomorphy). In C. suevicus (GPIT-PV-31381, SMNS 9808, SMNS 90513) the distal-most seven preflexural vertebrae have neural spines that are oriented very strongly posteriorly, with their posterior margin lying on top of the prezygapophyses of the according posterior vertebra. These neural spines appear almost rod-like in lateral view. The three vertebrae anterior to them have a similar morphology, but the neural spines are raised such that they do not overlap the prezyapophyses of the vertebrae immediately posterior.

Cricosaurus albersdoerferi (BMMS-BK 1-2) can be distinguished based on: 1) presence of pronounced reception pits on the lateral margins of the anterior and mid-maxilla for dentary tooth crowns (shared with C. bambergensis NKMB-P-Watt14/ 274); 2) presence of pronounced reception pits on the lateral margins of the mid-dentary (autapomorphy); 3) having the 'subrectangular' dorsal neural spine shape of $C$. suevicus, but differing in that $C$. albersdoerferi does not have the spines in close proximity (as in C. suevicus), and 4 ) the unique composition of the tail, sharing the same suite of fluke apomorphies with $C$. suevicus, but lacking the rod-like preflexural neural spines seen in $C$. suevicus. As such, $C$. albersdoerferi has a curious mix of features shared with both $C$. bambergensis and C. suevicus, perhaps resembling an intermediate form.

The two L. ulmense Subzone species are distinguishable based on: 1) shifts in tooth arrangement (evidenced by the dramatic shift in reception pit morphology), 2) change in dorsal neural spine shape, and 3 ) the composition of the tail displacement unit and fluke. Therefore, it looks as though they are differentiating in terms of feeding ecology and locomotion; and from a morphology that had already changed from that of $C$. bambergensis (NKMB-P-Watt14/274; Sachs et al., 2019).

Unfortunately, the early Tithonian fossil record for Cricosaurus is poor. Most of the early Tithonian material has been referred to $C$. elegans, although whether this is correct or not is impossible to say. The most prominent exception is the holotype of $C$. medius. Postcranial elements (with the exception of the anterior cervical vertebrae) are largely unknown from these horizons. As can be seen above, the three late Kimmeridgian taxa have very distinct postcrania. Cricosaurus elegans and $C$. medius share with $C$. suevicus the lack of pro- 
TABLE 2. List of Cricosaurus specimens from Southern Germany.

\begin{tabular}{|c|c|c|c|c|c|}
\hline Specimen & $\begin{array}{l}\text { German } \\
\text { Zone }\end{array}$ & Formation & Age & Tethyan ammonite zones & Locality \\
\hline $\begin{array}{l}\text { SNSB-BSPG AS I } \\
504 \text { (C. elegans } \\
\text { holotype) }\end{array}$ & $\begin{array}{l}\text { Malm } \\
\text { Zeta } 3\end{array}$ & $\begin{array}{l}\text { Mörnsheim } \\
\text { Formation }\end{array}$ & Early Tithonian & $\begin{array}{l}\text { Uppermost Hybonoticeras } \\
\text { hybonotum Zone }\end{array}$ & Daiting, Bavaria \\
\hline $\begin{array}{l}\text { SNSB-BSPG AS } \\
\text { VI } 2 \text { (C. medius } \\
\text { holotype) }\end{array}$ & $\begin{array}{l}\text { Malm } \\
\text { Zeta } 3\end{array}$ & $\begin{array}{l}\text { Mörnsheim } \\
\text { Formation }\end{array}$ & Early Tithonian & $\begin{array}{l}\text { Uppermost Hybonoticeras } \\
\text { hybonotum Zone }\end{array}$ & Daiting, Bavaria \\
\hline $\begin{array}{l}\text { BSPG } 1977 \text { XIX } \\
38\end{array}$ & $\begin{array}{l}\text { Malm } \\
\text { Zeta } 3\end{array}$ & $\begin{array}{l}\text { Mörnsheim } \\
\text { Formation }\end{array}$ & Early Tithonian & $\begin{array}{l}\text { Uppermost } H \text {. hybonotum } \\
\text { Zone }\end{array}$ & Daiting, Bavaria \\
\hline $\begin{array}{l}\text { NHMUK PV OR } \\
43005\end{array}$ & $\begin{array}{l}\text { Malm } \\
\text { Zeta 2b }\end{array}$ & $\begin{array}{l}\text { Altmühltal } \\
\text { Formation }\end{array}$ & Early Tithonian & $\begin{array}{l}\text { Lithacoceras rueppellianum } \\
\text { Subzone, } H \text {. hybonotum } \\
\text { Zone }\end{array}$ & Solnhofen, Bavaria \\
\hline $\begin{array}{l}\text { NHMUK PV OR } \\
37006\end{array}$ & $\begin{array}{l}\text { Malm } \\
\text { Zeta 2b }\end{array}$ & $\begin{array}{l}\text { Altmühltal } \\
\text { Formation }\end{array}$ & Early Tithonian & $\begin{array}{l}\text { L. riedense Subzone, } \\
H \text {. hybonotum Zone }\end{array}$ & Eichstätt, Bavaria \\
\hline $\begin{array}{l}\text { BMMS-BK 1-2 } \\
\text { (C. albersdoerferi } \\
\text { sp. nov. holotype) }\end{array}$ & $\begin{array}{l}\text { Malm } \\
\text { Zeta } 1\end{array}$ & $\begin{array}{l}\text { Arnstorf Member, } \\
\text { Torleite Formation }\end{array}$ & $\begin{array}{l}\text { Late } \\
\text { Kimmeridgian }\end{array}$ & $\begin{array}{l}\text { L. ulmense Subzone, } \\
\text { H. beckeri Zone }\end{array}$ & $\begin{array}{l}\text { Rygol quarry, Painten, } \\
\text { Bavaria }\end{array}$ \\
\hline GPIT-PV-31380 & $\begin{array}{l}\text { Malm } \\
\text { Zeta } 1\end{array}$ & $\begin{array}{l}\text { Nusplingen } \\
\text { Formation }\end{array}$ & $\begin{array}{l}\text { Late } \\
\text { Kimmeridgian }\end{array}$ & $\begin{array}{l}\text { L. ulmense Subzone, } \\
\text { H. beckeri Zone }\end{array}$ & $\begin{array}{l}\text { Nusplingen, Baden- } \\
\text { Württemberg }\end{array}$ \\
\hline GPIT-PV-31381 & $\begin{array}{l}\text { Malm } \\
\text { Zeta } 1\end{array}$ & $\begin{array}{l}\text { Nusplingen } \\
\text { Formation }\end{array}$ & $\begin{array}{l}\text { Late } \\
\text { Kimmeridgian }\end{array}$ & $\begin{array}{l}\text { L. ulmense Subzone, } \\
\text { H. beckeri Zone }\end{array}$ & $\begin{array}{l}\text { Nusplingen, Baden- } \\
\text { Württemberg }\end{array}$ \\
\hline $\begin{array}{l}\text { SMNS } 9808 \\
\text { (C. suevicus } \\
\text { lectotype) }\end{array}$ & $\begin{array}{l}\text { Malm } \\
\text { Zeta } 1\end{array}$ & $\begin{array}{l}\text { Nusplingen } \\
\text { Formation }\end{array}$ & $\begin{array}{l}\text { Late } \\
\text { Kimmeridgian }\end{array}$ & $\begin{array}{l}\text { L. ulmense Subzone, } \\
\text { H. beckeri Zone }\end{array}$ & $\begin{array}{l}\text { Nusplingen, Baden- } \\
\text { Württemberg }\end{array}$ \\
\hline SMNS 90513 & $\begin{array}{l}\text { Malm } \\
\text { Zeta } 1\end{array}$ & $\begin{array}{l}\text { Nusplingen } \\
\text { Formation }\end{array}$ & $\begin{array}{l}\text { Late } \\
\text { Kimmeridgian }\end{array}$ & $\begin{array}{l}\text { L. ulmense Subzone, } \\
\text { H. beckeri Zone }\end{array}$ & $\begin{array}{l}\text { Nusplingen, Baden- } \\
\text { Württemberg }\end{array}$ \\
\hline $\begin{array}{l}\text { NKMB-P-Watt14/ } \\
274 \\
\text { (C. bambergensis } \\
\text { holotype) }\end{array}$ & $\begin{array}{l}\text { Malm } \\
\text { Delta } 4\end{array}$ & $\begin{array}{l}\text { Wattendorf Member, } \\
\text { Torleite Formation }\end{array}$ & $\begin{array}{l}\text { Late } \\
\text { Kimmeridgian }\end{array}$ & $\begin{array}{l}\text { Aulacostephanus } \\
\text { pseudomutabilis Zone }\end{array}$ & $\begin{array}{l}\text { Wattendorf quarry, } \\
\text { Wattendorf, Bavaria }\end{array}$ \\
\hline
\end{tabular}

nounced, or regular shallow, reception pits on the lateral margins of the middle maxilla and dentary. While this hints to a closer relationship between these three species, more postcranial material from the early Tithonian is needed to be certain.

Our phylogenetic analyses corroborates this: 1) as four of the Southern German species form a subclade within Cricosaurus that is the sister clade to all other Cricosaurus species; 2) C. bambergensis is basal to both C. suevicus and C. albersdoerferi; and 3) the other German species ( $C$. rauhuti and $C$. schroederi) appear to be basal members of 'subclade B'. As discussed above, the lack of resolution in 'subclade $A$ ' is caused by the dearth of postcranial material from the early Tithonian of Germany ( $C$. elegans is scored exclusively for craniodental characters), and C. puelchorum lacking postcranial remains as well. Moreover, we have not scored $C$. medius as none of the authors have seen the holotype first-hand.

\section{REVISED DIAGNOSES FOR THE LATE JURASSIC GERMAN SPECIES OF CRICOSAURUS}

With the recent description of NKMB-PWatt14/274 as C. bambergensis (Sachs et al. 2019), and the discovery of a new complete skeleton from Southern Germany that we name $C$. albersdoerferi, we herein have revised the species diagnoses for three of the members of 'subclade A' - those from the late Kimmeridgian-early Tithonian of Southern Germany. We have decided to exclude $C$. medius from a revised diagnosis as the specimen has not been seen first-hand, and it is already being studied by other workers (Y. Herrera, personal commun. 2019). All information concerning C. medius comes to us via Y. Herrera (personal commun. 2019). Note, we do not need to re-diagnose the newly established species $C$. rauhuti as it is from a different Cricosaurus subclade, and it was named and diagnosed recently by Herrera et al. (2021a). 
Cricosaurus elegans (Wagner, 1852) Wagner, 1858

V*1852 Stenosaurus elegans sp. nov. - Wagner, p. 98 , pl. 14. [sic]

v 1858 Cricosaurus elegans (Wagner) gen. et comb. nov. - Wagner, p. 22, Taf. 14, figure 1-2.

v 1888a Metriorhynchus elegans (Wagner) comb. nov. - Lydekker, p. 98.

v 1973 Cricosaurus elegans (Wagner) - Steel, p. 42.

v 2009 Cricosaurus elegans (Wagner) - Young and Andrade, p. 557, figure 6.

v 2010 Cricosaurus elegans (Wagner) - Young et al., p. 804.

v 2019 Cricosaurus elegans (Wagner) - Sachs et al., p. 1, figure $9 b$.

Holotype. SNSB-BSPG AS I 504: complete cranium preserved in lithographic limestone (Figure 9C).

Type locality. Daiting, Bavaria, Germany.

Type formation. Mörnsheim Formation

Type horizon. Subplanites moernsheimensis Subzone, Hybonoticeras hybonotum Tethyian ammonite Zone, lower Tithonian, Upper Jurassic.

Etymology. 'Slender ring lizard'.

Referred specimens. SNSB-BSPG 1977 XIX 38: skull preserved in lithographic limestone (from Daiting; Mörnsheim Formation).

The referral of these two specimens from the Altmühltal Formation was made by Lydekker (1888) and is here considered tentative: NHMUK PV OR 37006: poorly preserved rostrum in lithographic limestone (from Solnhofen); NHMUK PV OR 43005: poorly preserved skull and vertebral column in lithographic limestone (from Eichstätt).

Geological range. Upper Jurassic. Hybonoticeras hybonotum Tethyian ammonite Zone, lower Tithonian.

Emended diagnosis. A member of Cricosaurus with the following unique combination of characters: dentition lacking conspicuous enamel ornamentation; tooth crowns in the premaxilla, maxilla and dentary show distinct labiolingual compression (shared with $C$. albersdoerferi BMMS-BK 1-2, C. bambergensis NKMB-P-Watt14/274 and C. suevicus GPIT-PV-31381, SMNS 9808, SMNS 90513); lack of pronounced, or regular shallow, reception pits on the lateral margins of the middle maxilla and dentary (shared with $C$. medius SNSB-BSPG AS VI 2 and C. suevicus GPIT-PV-31381, SMNS 9808, SMNS 90513).
Cricosaurus elegans shares the following synapomorphy with $C$. albersdoerferi (BMMS-BK 1-2), C. medius (SNSB-BSPG AS VI 2) and C. suevicus (GPIT-PV-31381, SMNS 9808, SMNS 90513): 1) the maxillary tooth row terminates either anterior to, or approximately level to the anterior-margin of the orbits.

Note. Unfortunately, the C. elegans holotype, and all early Tithonian specimens, are only known from cranial material (or associated cervical vertebrae). Therefore, the dorsal neural spine and tail autapomorphies of the other taxa cannot be compared against the early Tithonian material. We herein refrain from synonymising $C$. elegans with $C$. medius and $C$. suevicus until early Tithonian Cricosaurus postcranial anatomy is: 1) discovered, and 2) better understood. As, the surprising variation in late Kimmeridgian Cricosaurus specimens means we cannot automatically assume conspecificity (the newly described species $C$. rauhuti from the early Tithonian helps reinforce our reticence).

Cricosaurus suevicus (Fraas, 1901) Young and Andrade, 2009

v*1901 Geosaurus suevicus sp. nov. - Fraas, p. 410.

v 1902 Geosaurus suevicus (Fraas) - Fraas p. 41, figure 7 Taf. 5-8.

v1 973 Geosaurus suevicus (Fraas) - Steel, p. 44, figure 18 (2-3).

v 2005 Geosaurus suevecicus (Fraas) - Mueller-Töwe, p. 211. [sic]

v 2009 Cricosaurus suevicus (Fraas) comb. nov. - Young and Andrade, p. 557, figure 6.

v 2010 Cricosaurus suevicus (Fraas) - Young et al., p. 802, figure 1 , figure 5 .

v 2019 Cricosaurus suevicus (Fraas) - Sachs et al., p. 1.

Lectotype. SMNS 9808: complete skeleton preserved in limestone (Figures 9D, 10B).

Type locality. Nusplingen, Baden-Württemberg, Germany.

Type formation. Nusplingen Formation.

Type horizon. Lithacoceras ulmense Subzone, Hybonoticeras hybonotum Tethyian ammonite Zone, lower Tithonian, Upper Jurassic.

Etymology. 'Swabian ring lizard'.

Referred specimens. SMNS 90513: almost complete skeleton preserved in limestone (Figure 9); GPIT-PV-31380: incomplete skeleton; GPIT-PV31381: largely complete skeleton (Figures 8D, 9A). All referred specimens are from the Nusplingen Formation. 
Geological range. Upper Jurassic. Lithacoceras ulmense Subzone, Hybonoticeras beckeri Tethyian ammonite Zone, upper Kimmeridgian.

Emended diagnosis. A member of Cricosaurus with the following unique combination of characters (proposed autapomorphic characters are indicated by an asterisk *): bicarinate dentition, lacking conspicuous enamel ornamentation; tooth crowns in the premaxilla, maxilla and dentary show distinct labiolingual compression (shared with $C$. albersdoerferi BMMS-BK 1-2, C. bambergensis NKMB-PWatt14/274 and C. elegans SNSB-BSPG AS I 504); lack of pronounced, or regular shallow, reception pits on the lateral margins of the middle maxilla and dentary (shared with $C$. elegans SNSB-BSPG AS I 504 and C. medius SNSBBSPG AS VI 2); all the neural spines of the dorsal vertebrae are rectangular when see in lateral view, a flat dorsal margin is the most prevalent (shared with $C$. albersdoerferi BMMS-BK 1-2), and the neural spines of adjacent vertebrae are in close proximity to one another*; estimated to have approximately 50 , or more, caudal vertebrae; morphology of the tail displacement unit: the distalmost seven preflexural vertebrae have neural spines that are oriented very strongly posteriorly, with their posterior margin lying on top of the prezygapophyses of the adjacent vertebra; the distalmost three preflexural neural spines appear almost rod-like in lateral view*; the three vertebrae anterior to them have a similar morphology, but the neural spines are raised such that they do not overlap the prezyapophyses of the vertebrae immediately posterior*.

Cricosaurus suevicus shares the following synapomorphy with $C$. elegans (SNSB-BSPG AS I 504), C. medius (SNSB-BSPG AS VI 2) and C. albersdoerferi (BMMS-BK 1-2): 1) the maxillary tooth row terminates anterior to, or approximately level to, the anterior-margin of the orbits.

Cricosaurus suevicus shares the following tail fluke synapomorphies with $C$. albersdoerferi (BMMS-BK 1-2): 1) the distal-most preflexural vertebra (also identifiable as it has a verticalized neural spine) has a dorsoventrally deep hemapophysis, with a midline flange (i.e., it does not have a 'rod-like' hemapophysis as in C. bambergensis NKMB-P-Watt14/274 and Rhacheosaurus gracilis NHMUK PV R 3948); 2) the five-six proximal-most flexural vertebrae have strongly anteriorly oriented neural spines (much more so than C. bambergensis NKMB-P-Watt14/274, $R$. gracilis NHMUK PV R 3948 and Thalattosuchus superciliosus GPIT-PV-31379); 3) the flexural hemapophyses contact one another along their posteroventral-anterodorsal margins (not their posterior-anterior margins as in $C$. bambergensis NKMB-P-Watt14/274, $R$. gracilis NHMUK PV R 3948 and T. superciliosus GPIT-PV-31379); and 4) the distal-most post-flexural hemapophyses retain their dorsoventrally deep profile (i.e., they do not return to a 'rod-like' morphology, as in C. bambergensis NKMB-P-Watt14/274 and $R$. gracilis NHMUK PV R 3948).

Cricosaurus bambergensis Sachs et al., 2019 v*2019 Cricosaurus bambergensis sp. nov. Sachs et al., p. 1, figs.3-7, 9a.

Holotype. NKMB-P-Watt14/274: almost complete skeleton preserved in lithographic limestone (Figures 9B, 10D).

Type locality. Kalk- und Dolomitbruch der Andreas Schorr GmbH, Wattendorf, Bamberg district, Bavaria, Southern Germany.

Type horizon. Wattendorf Member, Torleite Formation. Aulacostephanus pseudomutabilis Tethys ammonite Zone, upper Kimmeridgian, Upper Jurassic.

Etymology. 'Ring lizard from Bamberg'. Geological range. Upper Jurassic. Aulacostephanus pseudomutabilis, Tethys ammonite Zone, upper Kimmeridgian.

Emended diagnosis. A member of Cricosaurus with the following unique combination of characters (proposed autapomorphic characters are indicated by an asterisk *): bicarinate dentition, lacking conspicuous enamel ornamentation; tooth crowns in the premaxilla, maxilla and dentary show distinct labiolingual compression (shared with $C$. albersdoerferi BMMS-BK 1-2, C. suevicus SMNS 9808 and C. elegans SNSB-BSPG AS I 504); the maxillary tooth row clearly continues posteriorly past the anterior-margin of the orbit (thalattosuchian symplesiomorphy); presence of pronounced reception pits on the lateral margins of the anterior and middle maxilla for dentary tooth crowns (shared with $C$. albersdoerferi BMMS-BK 1-2); palatines have a distinct midline ridge with paired depressions either side* $^{*}$ estimated to have approximately 50 , or more, caudal vertebrae; morphology of the tail displacement unit: the distal-most three preflexural vertebrae have neural spines that are oriented strongly posteriorly, their posterior margin lies on top of the prezygapophyses of adjacent vertebra; however, these neural spines do not have the almost rod-like appearance (in lateral view) that $C$. suevicus (SMNS 9808) has; the three vertebrae anterior to them have a similar morphology, but the 
neural spines look more like a 'regular' neural spine, albeit strongly oriented posteriorly*.

Cricosaurus bambergensis retains the following four metriorhynchid tail fluke symplesiomorphies (unlike C. albersdoerferi BMMS-BK 1-2 and C. suevicus SMNS 9808, GPIT-PV-31381): 1) the distal-most preflexural caudal vertebra has a rodlike hemapophysis; 2) the proximal-most five or six flexural vertebrae have anteriorly oriented neural spines, but not strongly oriented anteriorly; 3 ) the flexural hemapophyses contact one another along their anterior-posterior margins; and 4) the distalmost post-flexural hemapophysis return to a 'rodlike' morphology (modified from Sachs et al., 2019).

\section{ACKNOWLEDGEMENTS}

We are grateful to R. Albersdörfer for providing the specimen to science. We are further indebted to M. Röper (BMMS), M. Mäuser (NKMB),
D. Vasylian (GPIT), as well as E. Maxwell and G. Schweigert (SMNS) for giving access to material under their care. We would also like to thank $Y$. Herrera (National University of La Plata, Buenos Aires, Argentina) for information on the specimens in SNSB-BSPG. F. Spindler and $\mathrm{H}$. Tischlinger are thanked for useful discussions and for providing additional UV-photos of the specimen. D. Schnabel allowed us to use his Cricosaurus drawing for Figure 2. MTY is financially supported by a Leverhulme Trust Research Project grant (RPG-2017167) and received support for his collections visit to Southern Germany (DE-TAF-5132) from the SYNTHESYS Project (www.synthesys.info/), which is financed by European Community Research Infrastructure Action under the FP7 'Capacities' Program.

Finally, we want to thank the anonymous reviewers who helped to improve the quality of this paper.

\section{REFERENCES}

Andrade, M.B., Young, M.T., Desojo, J.B., and Brusatte, S.L. 2010. The evolution of extreme hypercarnivory in Metriorhynchidae (Mesoeucrocodylia: Thalattosuchia) based on evidence from microscopic denticle morphology. Journal of Vertebrate Paleontology, 30(5):1451-1465. https://doi.org/10.1080/02724634.2010.501442

Andrews, C.W. 1913. A Descriptive Catalogue of the Marine Reptiles of the Oxford Clay, Part II. British Museum (Natural History), London. https://doi.org/10.5962/bhl.title.61785

Arratia, G., Schultze, H.P., Tischlinger, H., and Viohl, G. (eds.) 2015. Solnhofen - Ein Fenster in die Jurazeit. Verlag Dr. Friedrich Pfeil, Munich.

Buchy, M.-C., Vignaud, P., Frey, E., Stinnesbeck, W., and González, A.H.G. 2006. A new thalattosuchian crocodyliform from the Tithonian (Upper Jurassic) of northeastern Mexico. Comptes Rendus Palevol, 5:785-794. https://doi.org/10.1016/j.crpv.2006.03.003

Fitzinger, L.J.F.J. 1843. Systema Reptilium. Braumüller et Seidel, Vienna.

Foffa, D. and Young, M.T. 2014. The cranial osteology of Tyrannoneustes lythrodectikos (Crocodylomorpha: Metriorhynchidae) from the Middle Jurassic of Europe. PeerJ, 2:e608. https://doi.org/10.7717/peerj.608

Foffa D., Young, M.T., Brusatte, S.L., Graham, M.R., and Steel, L. 2018. A new metriorhynchid crocodylomorph from the Oxford Clay Formation (Middle Jurassic) of England, with implications for the origin and diversification of Geosaurini. Journal of Systematic Palaeontology, 16:11123-1143. https://doi.org/10.1080/14772019.2017.1367730

Foffa, D., Johnson, M.M., Young, M.T., Steel, L., and Brusatte, S.L. 2019. Revision of the Late Jurassic deep-water teleosauroid crocodylomorph Teleosaurus megarhinus Hulke, 1871 and evidence of pelagic adaptations in Teleosauroidea. PeerJ, 7:e6646. https://doi.org/10.7717/peerj.6646

Foth, C., Tischlinger, H., and Rauhut, O.W. 2014. New specimen of Archaeopteryx provides insights into the evolution of pennaceous feathers. Nature, 511(7507):79-82.

Fraas, E. 1901. Die Meerkrokodile (Thalattosuchia n. g.) eine neue Sauriergruppe der Juraformation. Jahreshefte des Vereins für vaterländische Naturkunde in Württemberg, 57:409-418.

Fraas, E. 1902. Die Meer-Crocodilier (Thalattosuchia) des oberen Jura unter specieller Berücksichtigung von Dacosaurus und Geosaurus. Palaeontographica, 49:1-72. 
Frey, E. and Tischlinger, H. 2015. Krokodile (Crocodyliformes), p. 448-458. In Arratia, G., Schultze, H. P., Tischlinger, H., and Viohl, G. (eds.), Solnhofen - Ein Fenster in die Jurazeit. Verlag Dr. Friedrich Pfeil, Munich.

Frey, E., Buchy, M.-C., Stinnesbeck, W., and López-Oliva, J.G. 2002. Geosaurus vignaudi n.sp. (Crocodyliformes: Thalattosuchia), first evidence of metriorhynchid crocodilians in the Late Jurassic (Tithonian) of central-east Mexico (State of Puebla). Canadian Journal of Earth Sciences, 39:1467-1483. https://doi.org/10.1139/e02-060

Gasparini, Z.B. and Dellapé, D. 1976. Un nuevo cocodrilo marino (Thalattosuchia, Metriorhynchidae) de la Formación Vaca Muerta (Jurasico, Tithoniano) de la Provincia de Neuquén (República Argentina). Congreso Geológico Chileno, 1:c1-c21.

Gasparini, Z., Pol, D., and Spalletti, L.A. 2006. An unusual marine crocodyliform from the Jurassic-Cretaceous boundary of Patagonia. Science, 311:70-73. https://doi.org/10.1126/science.1120803

Goloboff, P.A. 2014. Extended implied weighting. Cladistics, 30:260-272. https://doi.org/10.1111/cla.12047

Goloboff, P.A. and Catalano, S.A. 2016. TNT version 1.5, including a full implementation of phylogenetic morphometrics. Cladistics, 32:221-238. https://doi.org/10.1111/cla.12160

Goloboff, P.A., Farris, J.S., and Nixon, K.C. 2008. TNT, a free program for phylogenetic analysis. Cladistics, 24:774-786. https://doi.org/10.1111/j.1096-0031.2008.00217.x

Haug, C., Reumer, J.W.F., Haug, J.T., Arillo, A., Audo, D., Azar, D., Baranov, V., Beutel, R., Charbonnier, S., Feldmann, R., Foth, C., Fraaije, R.H.B., Frenzel, P., Gašparič, R., Greenwalt, D.E., Harms, D., Hyžný, M., Jagt, J.W.M., Jagt-Yazykova, E.A., Jarzembowski, E., Kerp, H., Kirejtshuk, A.G., Klug, C., Kopylov, D.S., Kotthoff, U., Kriwet, J., Kunzmann, L., McKellar, R.C., Nel, A., Neumann, C., Nützel, A., Perrichot, V., Pint, A., Rauhut, O., Schneider, J.W., Schram, F.R., Schweigert, G., Selden, P., Szwedo, J., van Bakel, B.W.M., Eldijk, T.v., Vega, F.J., Wang, B., Wang, Y., Xing, L., and Reich, M. 2020. Comment on the letter of the Society of Vertebrate Paleontology (SVP) dated April 21, 2020 regarding "Fossils from conflict zones and reproducibility of fossil-based scientific data": the importance of private collections. PalZ, 94:413-429. https://doi.org/10.1007/s12542-020-00522-x

Hay, O.P. 1930. Second Bibliography and Catalogue of the Fossil Vertebrata of North America 2. Carnegie Institute Washington, Washington, D.C.

Herrera, Y., Fernández, M.S., and Varela, J.A. 2009. Morfología del miembro anterior de Geosaurus araucanensis Gasparini y Dellapé, 1976 (Crocodyliformes: Thalattosuchia). Ameghiniana, 46:657-667.

Herrera, Y., Gasparini, Z., and Fernandez, M.S. 2013a. A new Patagonian species of Cricosaurus (Crocodyliformes, Thalattosuchia): first evidence of Cricosaurus in MiddleUpper Tithonian lithographic limestones from Gondwana. Palaeontology, 56:663-678. https://doi.org/10.1111/pala.12010

Herrera, Y., Fernández, M.S., and Gasparini, Z. 2013b. Postcranial skeleton of Cricosaurus araucanensis (Crocodyliformes: Thalattosuchia): morphology and palaeobiological insights. Alcheringa, 37:285-298. https://doi.org/10.1080/03115518.2013.743709

Herrera, Y., Gasparini, Z., and Fernández, M.S. 2015. Purranisaurus potens Rusconi, an enigmatic metriorhynchid from the Late Jurassic-Early Cretaceous of the Neuquén Basin. Journal of Vertebrate Paleontology, 35:e904790. https://doi.org/10.1080/02724634.2014.904790

Herrera, Y., Fernández, M.S., Lamas, S.G., Campos, L., Talevi, M., and Gasparini, Z. 2017. Morphology of the sacral region and reproductive strategies of Metriorhynchidae: A counterinductive approach. Earth and Environmental Science Transactions of the Royal Society of Edinburgh, 106:247-255. https://doi.org/10.1017/s1755691016000165

Herrera, Y., Aiglstorfer, M., and Bronzati, M. 2021a. A new species of Cricosaurus (Thalattosuchia: Crocodylomorpha) from southern Germany: the first three-dimensionally preserved Cricosaurus skull from the Solnhofen Archipelago. Journal of Systematic Palaeontology, 19(2):145-167. https://doi.org/10.1080/14772019.2021.1883138

Herrera, Y., Fernández, M.S., and Vennari, V.V. 2021b. Cricosaurus (Thalattosuchia, Metriorhynchidae) survival across the $\mathrm{J} / \mathrm{K}$ boundary in the High Andes (Mendoza Province, Argentina). Cretaceous Research, 118:104673. https://doi.org/10.1016/j.cretres.2020.104673 
Johnson, M.M., Young, M.T., and Brusatte, S.L. 2020. The phylogenetics of Teleosauroidea (Crocodylomorpha, Thalattosuchia) and implications for their ecology and evolution. PeerJ, 8:e9808. https://doi.org/10.7717/peerj.9808

Joyce, W.G. and Mäuser, M. 2020. New material of named fossil turtles from the Late Jurassic (late Kimmeridgian) of Wattendorf, Germany. PLoS ONE, 15:e0233483. https://doi.org/ 10.1371/journal.pone.0233483

Lydekker, R. 1888. Catalogue of the Fossil Reptilia and Amphibia in the British Museum (Natural History), Volume 1. Order of the Trustees, London. https://doi.org/10.5962/bhl.title.61848

Mallison, $\mathrm{H}$. and Wings, O. 2014. Photogrammetry in paleontology - a practical guide. Journal of Paleontological Techniques, 12:1-31.

Mueller-Töwe, I.J. 2005. Phylogenetic relationships of the Thalattosuchia. Zitteliana, A45:211213.

Nesbitt, S.J. 2011. The early evolution of Archosauria: relationships and the origin of major clades. Bulletin of the American Museum of Natural History, 352:1-292. https://doi.org/ 10.1206/352.1

Niebuhr, B. and Pürner, T. 2014. Plattenkalk und Frankendolomit-Lithostratigraphie der Weißjura-Gruppe der Frankenalb (außeralpiner Oberjura, Bayern). Schriftenreihe der Deutschen Gesellschaft für Geowissenschaften, 83:5-72. https://doi.org/10.1127/sdgg/83/2014/5

Ösi, M., Young, M.T., Galácz, A., and Rabi, M. 2018. A new large-bodied thalattosuchian crocodyliform from the Lower Jurassic (Toarcian) of Hungary, with further evidence of the mosaic acquisition of marine adaptations in Metriorhynchoidea. PeerJ, 6:e4668. https://doi.org/10.7717/peerj.4668

Rauhut, O.W., Foth, C., Tischlinger, H., and Norell, M.A. 2012. Exceptionally preserved juvenile megalosauroid theropod dinosaur with filamentous integument from the Late Jurassic of Germany. Proceedings of the National Academy of Sciences, 109(29):11746-11751. https://doi.org/10.1073/pnas.1203238109

Rauhut, O.W., Foth, C., and Tischlinger, H. 2018. The oldest Archaeopteryx (Theropoda: Avialiae): a new specimen from the Kimmeridgian/Tithonian boundary of Schamhaupten, Bavaria. PeerJ, 6:e4191. https://doi.org/10.7717/peerj.4191

Ristevski, J., Young, M.T., Andrade, M.B., and Hastings, A.K. 2018. A new species of Anteophthalmosuchus (Crocodylomorpha, Goniopholididae) from the Lower Cretaceous of the Isle of Wight, United Kingdom, and a review of the genus. Cretaceous Research, 84:340383. https://doi.org/10.1016/j.cretres.2017.11.008

Röper, M. 2005. Field Trip B: East Bavarian Plattenkalk - different types of Upper Kimmeridgian to Lower Tithonian Plattenkalk deposits and facies. Zitteliana, 26:57-70.

Sachs, S., Young, M.T., Abel, P., and Mallison, H. 2019. A new species of metriorhynchid crocodylomorph Cricosaurus from the Upper Jurassic of southern Germany. Acta Palaeontologica Polonica, 64(2):343-356. https://doi.org/10.4202/app.00541.2018

Sachs, S., Young, M.T., and Hornung, J.H. 2020. The enigma of Enaliosuchus, and a reassessment of the Lower Cretaceous fossil record of Metriorhynchidae. Cretaceous Research, 114:104479. https://doi.org/10.1016/j.cretres.2020.104479

Schweigert, G. 2007. Ammonite biostratigraphy as a tool for dating Upper Jurassic lithographic limestones from South Germany-first results and open questions. Neues Jahrbuch für Geologie und Paläontologie-Abhandlungen, 245(1):117-125. https://doi.org/10.1127/0077-7749/2007/0245-0117

Spindler, F. and Albersdörfer, R. 2019. Schatzkammer im Herzen Bayerns. Die einzigartigen Fossilfunde von Painten. Eigenverlag Dinosaurier-Park Altmühltal, Denkendorf.

Steel, R. 1973. Crocodylia, Handbuch der Paläoherpetologie Teil 16. Gustav Fischer Verlag, Stuttgart.

von Sömmerring, S.T. 1814. Über den Crocodilus priscus oder ein in Baiern versteint gefundenes schmalkieferiges Krokodil, Gavial der Vorwelt. Abhandlungen der MathematischPhysikalischen Classe der Königlich Bayerischen Akademie der Wissenschaften, 4:1-74.

von Sömmerring, S.T. 1816. Ueber die Lacerta gigantea der Vorwelt. Denkschriften der königlichen Akademie der Wissenschaften München, Mathematisch-Physikalischen Classe, 6:37-59.

Wagner, A. 1852. Neu-aufgefundene Saurier-Ueberreste aus den lithographischer Schiefern in dem oberen Jurakalke. Abhandlungen der Mathematisch-Physikalischen Classe der Königlich Bayerischen Akademie der Wissenschaften, 6:661-710. 
Wagner, A. 1858. Zur Kenntniss der Saurier aus den lithographischen Schiefern. Abhandlungen der Mathematisch-Physikalischen Classe der Königlich Bayerischen Akademie der Wissenschaften, 8:415-528.

Young, M.T., and Andrade, M.B. 2009. What is Geosaurus? Redescription of Geosaurus giganteus (Thalattosuchia: Metriorhynchidae) from the Upper Jurassic of Bayern, Germany. Zoological Journal of the Linnean Society, 157:551-585. https://doi.org/10.1111/j.1096-3642.2009.00536.x

Young, M.T., Brusatte, S.L., Ruta, M., and Andrade, M.B. 2010. The evolution of Metriorhynchoidea (Mesoeucrocodylia, Thalattosuchia): an integrated approach using geometric morphometrics, analysis of disparity, and biomechanics. Zoological Journal of the Linnean Society, 158(4):801-859. https://doi.org/10.1111/j.1096-3642.2009.00571.x

Young, M.T., Sachs, S., and Abel, P. 2018. Einblicke in die Evolution der Thalattosuchier Meereskrokodile des Mesozoikums. Fossilien, 3(2018):16-23.

Young, M.T., Sachs, S., Abel, P., Foffa, D., Herrera, Y., and Kitson, J.J.N. 2020a. Convergent evolution and possible constraint in the posterodorsal retraction of the external nares in pelagic crocodylomorphs. Zoological Journal of the Linnean Society, 189(2):494-520. https://doi.org/10.1093/zoolinnean/zlaa021

Young, M.T., Brignon, A., Sachs, S., Hornung, J., Foffa, D., Kitson, J.J.N., Johnson, M.M., and Steel, L. 2020b. Cutting the Gordian knot: a historical and taxonomic revision of the Jurassic crocodylomorph Metriorhynchus. Zoological Journal of the Linnean Society, zlaa092. https://doi.org/10.1093/zoolinnean/zlaa092 


\section{APPENDIX 1.}

High-resolution 3D digital photogrammetric models. All appendices are available for download in a zipped format at https://palaeo-electronica.org/content/2021/3371-a-new-cricosaurus-species.

\section{APPENDIX 2.}

High resolution 2D orthophoto. All appendices are available for download in a zipped format at https://palaeo-electronica.org/content/2021/3371-a-new-cricosaurus-species.

\section{APPENDIX 3.}

Details on the creation of the 3D digital photogrammetric models. All appendices are available for download in a zipped format at https://palaeo-electronica.org/content/2021/3371-a-new-cricosaurus-species.

\section{APPENDIX 4.}

Indication of skeletal parts which are covered by plaster or have been reconstructed. All appendices are available for download in a zipped format at https://palaeo-electronica.org/content/2021/ 3371-a-new-cricosaurus-species.

\section{APPENDIX 5.}

Phylogenetic character list and scoring sources. All appendices are available for download in a zipped format at https://palaeo-electronica.org/content/2021/3371-a-new-cricosaurus-species.

\section{APPENDIX 6.}

Matrix. All appendices are available for download in a zipped format at https://palaeo-electronica.org/content/2021/3371-a-new-cricosaurus-species.

\section{APPENDIX 7.}

Equal weight strict consensus topology. All appendices are available for download in a zipped format at https://palaeo-electronica.org/content/2021/3371-a-new-cricosaurus-species.

\section{APPENDIX 8.}

Strongly down-weighted strict consensus topology. All appendices are available for download in a zipped format at https://palaeo-electronica.org/content/2021/3371-a-new-cricosaurus-species.

\section{APPENDIX 9.}

Other weighted strict consensus topologies. All appendices are available for download in a zipped format at https://palaeo-electronica.org/content/2021/3371-a-new-cricosaurus-species. 